\title{
A FOGYASZTÓI ADÁSVÉTEL EGYES KÉRDÉSEINEK SZABÁLYOZÁSA ÉS JOGGYAKORLATA ROMÁNIÁBAN ${ }^{\mathrm{I}}$
}

\author{
SZÉKeLY JÁNOS
}

Debreceni Jogi Mühely, 2020. ÉVI (XVII. évfolyam) I-2. DOI I0.24I69/DJM/2020/I-2/4

\section{A szabályozás kialakulása és hatályos állapota}

A fogyasztóvédelem terén a román belső jogban alkalmazandó normák elsődleges és másodlagos - jogszabályok komplex szövevényét alkotják, olykor átfedő vagy éppen redundáns normatív tartalommal. Ez kihat a normák

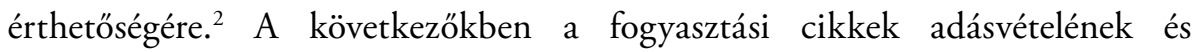
a kapcsolódó jótállásnak egyes vonatkozásairól szóló 1999/44/EK európai parlamenti és tanácsi irányelv ${ }^{3}$ (továbbiakban: 1999/44/EK irányelv) román belső jogba való átültetésének folyamatát szeretnénk ismertetni. Tanulmányunk vizsgálódási körét az 1999/44/EK irányelv tárgyi hatályához igazítjuk. Emiatt elemzésünk elsősorban az irányelv 1. cikk (2) bekezdésének e) pontjában meghatározott jótállás vonatkozásában az 1. cikk (2) bekezdésének a) pontjában definiált fogyasztók számára történő, az 1. cikk (2) bekezdésének b) pontjában meghatározott fogyasztási cikkek eladására nézve releváns jogi normákra korlátozódik. Itt szükséges megjegyezni, hogy a román jog a fogyasztási cikkek megnevezésére a termék (produs) kifejezést használja, emiatt ezt a tanulmányban a fogyasztási cikkekkel azonos jelentéstartalommal alkalmazzuk.

A román Polgári törvénykönyv ${ }^{4}$ (RPtk.) a fogyasztási szerződésekre nézve szubszidiárius jogforrást jelent, szabályai különös jogforrások hiányában alkalmazandók (RPtk. 1177. \$). Maga az RPtk. is tartalmaz a fogyasztóvédelem szempontjából fontosszabályokat, ideértve a vállalkozó (profesionist)

1 A tanulmány megírása és megjelentetése az Igazságügyi Minisztérium jogászképzés színvonalának emelését célzó programjai keretében valósult meg.

2 G. Piperea: Protecția consumatorilor în contractele comerciale. C. H. Beck, București, 2018, 9-10.

3 Az Európai Parlament és a Tanács 1999/44/EK irányelve (1999. május 25.) a fogyasztási cikkek adásvételének és a kapcsolódó jótállásnak egyes vonatkozásairól, HL L 171., 1999.7.7., 12-16.

4 A román Polgári törvénykönyv [Codul civil] a 2009. évi 287. törvény, újra-közzétéve a román Hivatalos Közlöny [Monitorul Oficial] 505/2011.07.15. számában. 
meghatározását ${ }^{5}$ [RPtk. 3. \$(2) és (3) bekezdések], bár a fogyasztó fogalmát nem definiálja. A polgári jog általános normái, amelyek az adásvételi szerződéseket szabályozzák, többek között a szavatosságra nézve tartalmaznak elöírásokat (az RPtk. 1672. és 1695-1718. \$-ai) és emiatt ezektől szintén nem lehetséges elvonatkoztatni. E normákra csupán abban a mértékben hivatkozunk majd, amennyiben alkalmazandók a vállalkozó-fogyasztó viszonyra.

\subsection{Az 1999/44/EK irányelv átültetése a román belső jogba}

Az 1999/44/EK irányelv átültetése a román belső jogba több jogszabály útján valósult meg. Ezek közül a legjelentősebb $A$ termékek eladására és a hozzá füzödö garanciákra vonatkozó 2003. évi 449. törvény (449/2003. tv.). ${ }^{6} \mathrm{Az}$ irányelv tartalmának a román belső jogba való átültetése még 2003-banmeg, négy évvel az ország csatlakozása előtt az Európai Unióhoz. A törvény a csatlakozás napjától (2007. január 1-től) lépett hatályba.?

$\mathrm{Az}$ átültetés a román Polgári törvénykönyv rendelkezésein kívül, más jogszabályok általvalósult meg, elsősorban annak tulajdoníthatóan, hogy az új Polgári törvénykönyv kodifikációja 2003-ban még nem zárult le. Másodsorban, mivel a vállalkozások és a fogyasztók közötti jogviszonyok szabályozása általában különálló törvényekbe foglalt különös normák formáját

5 A román Polgári törvénykönyv értelmében: „Vállalkozónak kell tekinteni mindenkit, aki vállalkozást üzemeltet” [RPtk. 3. \$ (2) bekezdés], ahol a vállalkozás üzemeltetése alatt „a dolgok elóállitásából, igazgatásából vagy elidegenitéséböl, illetve szolgáltatás-nyújtásból álló szervezett tevékenység”" rendszeres folytatását értjük, "függetlenül attól, hogy ez nyereségszerzésre irányul-e, vagy sem" [RPtk. 3. \$(3) bekezdés]. E meghatározás nem azonos a gazdálkodó szervezet (operator economic) fogalmával, amely az általános fogyasztóvédelmi jogszabályokban kerül említésre, ahol ez, mint „olyan természetes vagy jogi személy” van meghatározva, „amely vállalkozói tevékenysége során elöállit, importál, illetve fuvaroz termékeket, ezek alkatrészeit, vagy szolgáltatásokat nyújt, és erre engedéllyel rendelkezik"(21/1992. Korm. r. 2. \$3. pont); nem azonos továbbá az eladó fogalmával sem, amelyet a 449/2003. tv. alkalmaz. Utóbbi törvény az eladót a következőképpen határozza meg: „azon természetes vagy jogi személy, amely tevékenysége során termékekkel kereskedik egy a fogyasztóval kötött szerzödés feltételei szerint, és erre engedéllyel rendelkezik". Mindazonáltal a Polgári törvénykönyv hatálybaléptetésére vonatkozó átmeneti rendelkezéseket tartalmazó 2011. évi 71. törvény 8. \$-ának (1) bekezdése a vállalkozó fogalmát többek között a gazdálkodó szervezet fogalmát is magába foglalóként határozta meg. A vállalkozó fogalmának részletes leírásához a román jogban, lásd I. Schiau: Profesionistul, un reper al dăinuirii materiei comerciale în cadrul dreptului privat unitar. Revista Română de Drept al Afacerilor, 2015/7. 43-58.

6 A termékek eladásáról és a hozzá füződő garanciákról szóló 2003. évi 449. törvény [Legea 449/2003 privind vânzarea produselor si garanțiile asociate acestora] legutóbbi egységesített formájában a román Hivatalos Közlöny 347/2008.05.06. számában jelent meg.

7 I.-F. Popa: Obligația de conformitate - cu referire specială la vânzările de consum. Pandectele Române, 2005/5., 153. 
öltötte, a román jogrendszerben ${ }^{8}$ értelemszerünek tűnt a jogalkotó számára e szabályozási modell további követése. Harmadsorban az átültetés pillanatában a szerzödésszerü (megfeleló) teljesités elve - ahogyan annak jelentéstartalma az 1999/44/EK irányelvből kitünik - még idegennek tetszett a román jogban nyújtott más jogérvényesitési lehetöségek koncepciójához viszonyítva (a szerződéstől való elállás, a szerződés peres úton felbontása, a teljesítés peres úton kikényszerítése, amelyeket az 1864. évi román Polgári törvénykönyv 1020. és 1021. \$-ai szabályoztak, megerősítve a 970. \$ jóhiszemüségre vonatkozó rendelkezéseivel), illetve a rejtett hibák miatti eszközszavatosság, és a jogszavatosság a korábban hatályos Polgári törvénykönyv 1337-1351. és 13521360. \$-aiba foglalt rendelkezéseinek fényében. ${ }^{9}$ A román szakirodalom ${ }^{10}$ a fogyasztóvédelem területén már idejekorán felismerte a termék csekély (például kizárólag esztétikai) hibáival összefüggésben felvetődő dogmatikai nehézségeket. Ilyen hibák nem alapozhatták meg a szerződésszerű teljesítés kikényszerítését, sem pedig a szerződéstől való elállást, annak felbontását (a teljesítés elmaradásának okán), illetve megtámadását (a vevő részéről fennálló esetleges tévedés vagy megtévesztése jogalapjával), a termékfelelősséget, vagy a szavatosság valamely formájának érvényesítését, mivel a termék hibája kismértékű, és emiatt nem tekinthető lényegesnek. A szerződésszerűség elve az Európai Közösség tagjai közös joghagyománya részének tekinthető e tagság 1999. évi állása szerint [az 1999/44/EK irányelv preambulumának (7) bekezdése erre utal], de ez kimondottan $n e m^{11}$ volt része a román joghagyománynak az irányelv átültetésekor.

A fogyasztók védelméről szóló 1992. évi 21. kormányrendelet (21/1992. Korm. r.) ${ }^{12}$ is tartalmazott (és mindmáig tartalmaz) a nem szerződésszerü teljesítésre vonatkozó egyes szabályokat a fogyasztói szerződésekre vonatkozó jótállás terén. E jogszabály volt az első, amely Romániában a fogyasztóvédelem

8 Lásd N. Grădinaru: Regulile comunitare în materia vânzării bunurilor de consum și a garanțiilor acestora. Revista Română de Drept Comunitar, 2005/3., 54., 1. jegyzet. A szerző felsorolja a fogyasztói adásvételre vonatkozó normákat a 449/2003. tv. hatálybalépését megelőző időszakban.

9 Lásd I.-F. Popa, i. m., 2005, 154-161.

10 Lásd például J. Goicovici: Dreptul consumației. Sfera Juridică, Cluj-Napoca, 2006, 81-82.

11 I.-F. Popa, i.m., 2005, 154. Ugyanezen szerző későbbi írásában a román Polgári törvénykönyvet „vaknak és süketnek” (98.) nevezi amiatt, mert figyelmen kívül hagyta a szerződésnek való megfelelés modern fogalmát, amelyet a 449/2003. tv. is alkalmaz. I.-F. Popa: Conformitatea lucrului vândut - Între rigiditate tradițională și funcționalism (II). Revista Română de Drept Privat, 2009/2., 96. és 98.

12 A fogyasztók védelméről szóló 1992. évi 21. kormányrendelet [Ordonanța 21/1992 privind protecția consumatorilor] legutóbb a román Hivatalos Közlöny 208/2007.03.28. számában lett újra közzétéve. 
tárgykörét szabályozta, és amelyben a fogyasztó ${ }^{13}$ és a termék ${ }^{14}$ fogalmai meghatározásra kerültek, illetve, amely meghatározta a fogyasztók által vett javakra vonatkozó jótállás szabályait, valamint a fogyasztói egyesületek működését. Sok, a 449/2003. tv. eredeti szövegében található norma a 21/1992. Korm. rendeletből került átemelésre. ${ }^{15}$ Emiatt az 1999/44/EK irányelv átültetése nem a román jogban megszokott módon, egyszerü fordítással következett be, hanem tartalmának a már létező, komplex, bár nem teljeskörü, belső fogyasztóvédelmi rendszerbe történő beleágyazásával.

Végezetül, a Fogyasztói törvénykönyvről ${ }^{16}$ (Ftvk.) szóló 2004. évi 296. törvény szintén tartalmaz rendelkezéseket a termékek megfelelése vonatkozásában, valamint ezek címkézésére és a rájuk vonatkozó leírás - a termékdokumentáció - kialakítására nézve (sokkal tágabb megfogalmazásban, mint a 449/2003. tv. szövegében). Az Ftvk. rendelkezik az eladó általános kötelezettségéről, a nem megfelelő termék észszerű határidőn belüli, ingyenes kijavításárról vagy kicseréléséről, a fogyasztó számára lehető legkevesebb nehézséget okozva (ha az illető intézkedés nem bizonyul aránytalannak), a felek közötti szerződéses jogviszony feltételeinek tiszteletben tartásával (Ftvk. 15 -18. \$-ai).

13 E fogalom időben változékonynak bizonyult. Első meghatározását még a 21/1999. Korm. r. adta (2. \$, második nem számozott bekezdés) miszerint a fogyasztók: „olyan természetes személyek, akik gazdasági ügynököktöl [értsd vállalkozóktól - szerzö megj.] beszerzett termékeket végfelhasználóként felhasználnak vagy elfogyasztanak, illetve akik az ilyenek [értsd vállalkozók - szerző megj.] által nyújtott szolgáltatásokból részesülnek". Ez a meghatározás többször került módosításra. Az első ilyen módosítást a 2000. évi 58. kormányrendelet iktatta be (közzétéve a Hivatalos Közlöny 43/2000.01.31 számában), amelynek folytán a meghatározás a következőképpen alakult át: „olyan természetes személy, aki vállalkozói tevékenységén kivül eljárva termékeket vagy szolgáltatásokat vesz, felhasznál, illetve elfogyaszt". Ez később újra módosult, a 2002. évi 37. törvény által (közzétéve a román Hivatalos Közlöny 91/2002.02.02. számában), a következőképpen: „[egy] természetes személy vagy természetes személyek egyesületbe tömörült csoportja, aki vállalkozói tevékenységén kivül eljárva termékeket vagy szolgáltatásokat vesz, felhasznál, illetve elfogyaszt". A meghatározás végső formáját, amely ma közös a 449/2003. törvényben olvashatóval, „A kereskedők fogyasztókkal szembeni tisztességtelen magatartásának visszaszorításáról és a jogszabályok az európai fogyasztóvédelmi joggal történő harmonizálásáról szóló 2007. évi 363. törvény" [Legea 363/2007 privind combaterea practicilor incorecte ale comercianților in relatia cu consumatorii și armonizarea reglementărilor cu legislația europeană privind protecția consumatorilor] adta meg. Ez a román Hivatalos Közlöny 899/2007.12.28. számában került közzétételre. E meghatározás 21/1999. Korm. r. 2. \$2. pontjában került elhelyezésre, és tanulmányunk 2 . szakaszában olvasható.

14 A termék fogalmának értelmezéséért lásd I.-F. Popa, i. m., 2005, 164-165.

15 I.-F. Popa, i. m., 2005, 162.

16 A Fogyasztói törvénykönyv [Legea 296/2004 privind Codul consumului] hatályos változata a román Hivatalos Közlöny 224/2008.03.24. számában került újra-közzétételre egységesített formában. 


\subsection{A román szabályozás átültetést követő dinamikája}

A 449/2003. tv. szövegét elöször A kereskedökfogyasztókkalszembeni tisztességtelen magatartásának visszaszoritásáról és a jogszabályok az európai fogyasztóvédelmi joggal történö harmonizálásáról szóló 2007. évi 363. törvény módosította (mivel a 449/2003. tv. által nyújtott jótállás betartatása a tisztességtelen kereskedelmi magatartások visszaszorításának egyik eszköze ${ }^{17}$ - a 2007. évi 363. tv. 6. \$-a). Ennek eredményeként a fogyasztón ${ }^{18}$ fogalmának meghatározása módosult, az 1999/44/EK irányelv 1. cikk (2) bekezdés a) pontjának megfogalmazását tükrözve. A 449/2003. tv. és a 21/1992. Korm. r. később nagymértékben módosításra kerültek, az Egyes fogyasztóvédelmi vonatkozású jogszabályok módositására és kiegészitésére vonatkozó 2008. évi 174. sürgösségi kormányrendelet ${ }^{19}$ által, az Európai Bizottság szorgalmazására. ${ }^{20}$ A Bizottság korábban az 1999/44/EK irányelv román belsö jogba való átültetését elégtelennek minösitette. A módositás további okát azon redundanciák felszámolásának szükségessége adta, amelyeket a 21/1992. Korm. r. és a 449/2003. tv. általános fogyasztóvédelmi, és különösen a fogyasztók számára nyújtott jótállás terén fennálló szabályainak átfedése okozott.

17 J. Goicovici: Elementele constitutive ale practicilor comerciale neloiale în relațiile cu consumatorii. Studia Universitatis Babeş-Bolyai Iurisprudentia, 2016/3., 99. 7. jegyzet.

18 A 449/2003. törvénybe foglalt fogyasztó-meghatározás eredeti szövegezése a következő volt: „bármely természetes személy, vagy természetes személyek egyesületekbe tömörült csoportja, amely vállalkozói vagy kereskedelmi tevékenységén kivül, de a jelen törvénynek alávetett szerzödések keretein belül eljárva, termékeket vesz, beszerez, felhasznál, illetve elfogyaszt” [2. \$(1) bekezdés a) pont]. Ezt a 2007. évi 363. tv. a következőképpen módosította „bármely természetes személy vagy természetes személyek egyesületekbe tömörült csoportja, amely a jelen törvénynek alávetett szerzödések útján, kereskedelmi, ipari vagy termelési, kisipari vagy szabadfoglalkozású tevékenységén kivül esö céllal jár el." Lásd M. Iliescu: Aspecte teoretice privind noțiunea de consumator în legislația română. In: Politica legislativă între reglementare europeană, națională și internațională. Noi perspective ale dreptului, Conferința internațională de drept, studii europene și relații internaționale - București, 24-25 mai 2013, 587. Lásd továbbá M. Iliescu: Consumatorul - între prevederi legislative și opinii doctrinare. Curierul Judiciar, 2014/8. 436. Fontos, hogy ez a meghatározás nem azonos az ugyanazon 2007. évi 363. törvényben adott további meghatározással, amelyet az általa módosított 21/1992. Korm. rendeletbe helyezett el (részletekért lásd a 13. jegyzetet fentebb), ugyanis a 449/2003. tv. rendelkezéseinek alávetett szerzödésekben eljáró fogyasztókra vonatkozik, és nem a fogyasztókra általában, ahogyan azokat a 21/1992. Korm. r. meghatározza. E helyzet korábban egymással össze nem egyeztethető fogyasztó-meghatározásokat eredményezett. Lásd I.-F. Popa, i. m., 2005, 163.

19 Az Egyes fogyasztóvédelmi vonatkozású jogszabályok módosításáról és kiegészítéséről szóló2008. évi 174. sürgősségi kormányrendelet [Ordonanța de urgență 174/2008 pentru modificarea și completarea unor acte normative privind protecția consumatorilor] a román Hivatalos Közlöny 795/2008.11.27. számában került közzétételre.

20 A 2008. évi 174. sürgősségi kormányrendelet indokolása, (http://arhiva.gov.ro/uploadlarticles/103997/2763nf-protectia-consumatorilor-tot.pdf, letöltés dátuma: 2019.12.20) tartalmaz egy hivatkozást az 1999/44/EK irányelv nem teljes átültetésére nézve, amelyet az Európai Bizottság 2008. január 18-i levelében kifogásolt. 
A kijavitás meghatározása - amelyet a 449/2003. tv. 2. \$-ának f) pontja tartalmaz - módosításra került, annak érdekében, hogy az általánosságban véve nem megfelelő termék módositására vonatkozzon (ne pedig a jótállási jegy vagy a reklámok tartalmához képest nem megfelelö termékekre). A 449/2003. tv. kibővült a rejtett hibák ${ }^{21}$ és az átlagos használati idón ${ }^{22}$ meghatározásaival is [a 2. új g) és h) pontjai], amelyek nagyrészt a 21/1992. Korm. rendeletböl kerültek átvételre. Tisztázásra került, hogy a fogyasztó bármely követelését köteles az eladóval szemben megfogalmazni (449/2003. tv. módositott 10. S-a). A megfelelés helyreállitására vonatkozó különbözö - a 449/2003. tv. 11. S-ának (1) bekezdésébe foglalt - intézkedések sorrendjét a módositó jogszabály rögzitette, elöirva, hogy a fogyasztó elsödlegesen a termék kijavítását vagy kicserélését kérheti. Ugyanazon \$ (4) bekezdésénél a módosítás a kijavításra rendelkezésre álló maximális időtartamot 15 (naptári) napban rögzítette. Egy új, (5) bekezdés rendelkezettaz eladó azon kötelezettségéről, hogy csupán új alkatrészeket használjon fel a kijavítás során. A 449/2003. törvénybe újonnan beiktatott $16^{1}$. és $16^{2}$. \$-ok a jótállás érvényesítésére megszabott kétéves határidő meghosszabbítását írták elő a termék átlagos használati ideje mértékéig, amennyiben ez a kétéves határidőt meghaladná, mindazon esetekben, amikor a termék előállításakor figyelembe vett rendeltetése szerint nem használható e hibák bekövetkezte miatt, de csupán akkor, ha a rejtett hibák észlelésére az átlagos használati idő letelte előtt került sor (e normák a 21/1992. Korm. r. tartalmából kerültek átemelésre). ${ }^{23}$

21 A 449/2003. tv. 2. \$-ának g) pontjában meghatározott rejtett hibák „az átadott termék vagy szolgáltatás olyan minöségi fogyatékai, amelyek nem voltak ismertek a fogyasztó számára, és nem válhattak ismertté az ellenörzés szokványos eszközei által". Itt szükséges megjegyezni, hogy a rejtett hibák ilyen meghatározása eltér az RPtk. definíciójától, amely 1707. \$-ának (2) bekezdésében, a nem fogyasztási adásvételek esetében ezt olyan hibaként határozza meg „amely az átadás idöpontjában szakirányú segitség nélkül a gondos és körültekintö vevö részére sem felfedezhetö". Emiatt a szerződéses megfelelés tesztje rejtett hibák esetében a fogyasztói szerződésekben kevésbé szigorú.

22 Az átlagos használati idő a 449/2003. tv. 2. \$-ának h) pontja által, mint „azon idötartam, amelyet a normatív technikai dokumentáció tartalmaz, vagy amely a gyártó nyilatkozataiból kitünik, vagy amely a felek egyezségében meghatározást nyert, [és], amelyen belül a tartós felhasználású termékek müködési jellemzöiket meg kell örizzék, amennyiben azok szállitási, kezelési, raktározási és üzemeltetési feltételeinek betartása megtörtént." került meghatározásra. Itt érdemes megjegyeznünk, hogy ez a meghatározás alapvetően hibás, ugyanis tartalmában a tartós felhasználású termékekre vonatkoztat, amelyek meghatározása viszont visszautal az átlagos használati idötartamra (lásd a 63. jegyzetet lentebb), emiatt egy hibás, rekurzív (körkörös) definíció keletkezik mindkét fogalom esetében.

23 A fentebb felsorolt normák mindegyike bejelentésre került az Európai Unió részére az 1999/44/EK irányelv átültetésére szolgáló jogszabályként (https://eur-lex.europa.eu/legal-content/EN/NIM/?uri=celex:31999L0044, letöltés dátuma: 2020.01.12.). Azonban itt szükséges kiemelnünk, hogy egy további jogszabály is létezik, amely szintén az 1999/44/EK irányelv implementációjára született. Ez „A fogyasztók vállalkozókkal kötött szerződéseiből eredő jogaira, valamint egyes jogszabályok módosítására vonatkozó 2014. évi 34. sürgősségi 
A 449/2003. törvényt $A$ termékek eladására és a hozzá füzödö garanciákról szóló2003. évi 449. törvény módositásáról szóló 2016. évi 9. kormányrendelet $s$ módosította. ${ }^{24}$ A fogyasztó mindaddig önállómeghatározása a 449/2003. tv. szövegében megszűnt, e definíció csupán a 21/1992. Korm. r. 2. \$-ának 2. pontjában maradt fenn. Ezáltal felszámolásra kerültek a fogyasztó fogalmának vonatkozásában korábban párhuzamosan létező meghatározások,, 25 a 449/2003. tv. tárgyi hatálya így kiterjesztésre került. A jótállás fogalmát a jogalkotó a kereskedelmi jótállas ${ }^{26}$ fogalmával helyettesítette és bevezette a szerződéses megfelelőség miatti törvényes jótállás ${ }^{27}$ fogalmát. Utóbbi a fogyasztó számára nyújtott törvényi eredetü védelem jelentéstartalmával rendelkezik. Ennek alapján az eladó köteles a termék megfelelöségét - a jótállási jegyben vagy reklámokban állitott jellemzöit - helyreállitani a fogyasztó által fizetendö bármilyen további költség nélkül, a vételár visszatéritése, a termék kijavitása, vagy kicserélese uitján. A módositás továbbá bevezette a hosszú használati idejü termékek (a magyarországi szaknyelvben tartós fogyasztási cikkek) fogalmát [449/2003. tv. 2. \$, e) pont, a 21/1992. Korm. r.

kormányrendelet" [Ordonanța de urgență 34/2014 privind drepturile consumatorilor în cadrul contractelor incheiate cu profesioniștii, precum și pentru modificarea și completarea unor acte normative], amely a román Hivatalos Közlöny 427/2014.06.11. számában került közzétételre. Ez kötelezte a Nemzeti Fogyasztóvédelmi Hatóságot [Autoritatea Națională pentru Protecția Consumatorilor], hogy közölje az Európai Bizottsággal azon elfogadásra került fogyasztóvédelmi normákat, amelyek az 1999/44/EK irányelvnél szigorúbb rendelkezéseket tartalmaznak (a sürgősségi kormányrendelet $27^{1}$. \$-a).

24 A termékek eladására és a hozzá füződő garanciákra vonatkozó 2003. évi 449. törvény módosítására vonatkozó 2016. évi 9. kormányrendelet [Ordonanța 9/2016 pentru modificarea și completarea Legii nr. 449/2003 privind vânzarea produselor și garanțiile asociate acestora] a román Hivatalos Közlöny 66/2016.01.29. számában került közzétételre.

25 Részletekért lásd a 13. és 18. jegyzeteket fentebb.

26 A fogyasztói jótállást, amelyet a román jogszabály szó szerinti fordításban kereskedelmi garanciának nevez (elkülönítve azt a RPtk. adásvétel esetén alkalmazott jótállás-fogalmától - lásd pl. RPtk. 1716-1718. \$-ai), a 449/2003. tv. 2. \$-ának e) pontja határozza meg (jelenleg annak a 2019. évi 9. kormányrendelet által módosított formájában), a következőképpen: „az eladó által a fogyasztó iránt, további fizetési kötelezettség nélkül, vállalt bármely kötelezettség, a fogyasztó által fizetett vételár visszatéritésére, a megvett termék kijavitására vagy kicserélésére, azokban az esetekben, amikor az nem felel meg a jótállásra vonatkozó nyilatkozatokban vagy reklámokban kifejtett feltételeknek".

27 A fogyasztói szavatosságot, amelyet a román jogszabály szó szerinti fordításban törvényes megfelelési garanciának nevez, (elkülönítve azt a RPtk. adásvétel esetén alkalmazott szavatosság-fogalmától - lásd pl. RPtk. 16951715. \$-ai), a 449/2003. tv. 2. \$-ának e ${ }^{1}$ ) pontja határozza meg (annak a 2019. évi 9. kormányrendelet által módosított formájában), a következőképpen: „a fogyasztó jogi védelme, amely a törvény ereje által a megfelelöség hiányából ered, és az eladó azon törvényes kötelezettségét jelenti a fogyasztó irányábat, hogy további költségek igénylése nélkül a terméket a megfelelés állapotába hozza, ideértve a vételár a fogyasztónak történö visszaszolgáltatását, a termék kijavitása vagy kicserélése útján is, ha ez nem felel meg a jótállásra vonatkozó nyilatkozatokban vagy reklámokban kifejtett feltételeknek". A megfelelés vagy a megfelelés hiányának megállapítása elsősorban a felek feladata. Mindazonáltal, bármely szerződési előírás, amely kizárólag az eladó számára tartja fenn a megfelelés megállapítását, visszaélőnek minősül. D. Moțiu: Clauze abuzive în contractele încheiate cu consumatorii. Revista de Stiințe Juridice, 2013/1. 127. 
szövegéből átemelve]. A módosítás értelmében az eladó kötelezettsége a vételár visszatérítése, a termék kijavítása, illetve kicserélése vonatkozásában [449/2003. tv. 11. $\$(4)$ bekezdés] nem csupán a megfelelőség hiányának bejelentésétől számított 15 napon belül válik esedékessé, hanem 15 napon belül attól az időponttól is, amikor a termék nem megfelelő jellege következtében az eladóhoz visszaszolgáltatásra került. Ugyancsak e módosítás rögzítette az eladó azon kötelezettségét is, hogy a terméket azonos jellemzőkkel rendelkező más megfelelő termékre kell cserélni [449/2003. tv. 11. \$(6) bekezdés]. Bevezetésre került továbbá a jótállási jegy fogalma annak érdekében, hogy a román nyelvben bevett garanciafogalom különböző jelentéstartalmai között különbséget lehessen tenni. [A román jogi szaknyelvben a garancia (garanție) szó szövegkörnyezettől függően jelenthet jótállást, szavatosságot, illetve termékszavatosságot, vagy ezek mindegyikét. A jótállási jegy sokáig szintén garanciaként került megnevezésre.] A módosítás során a jogalkotó előírta az eladó azon kötelezettségét, hogy a vevő számára jótállási jegyet biztosításon minden tartós felhasználású termék eladása esetében. Az eladó kötelessé vált a fogyasztó jogaira vonatkozóan írásban információkat szolgáltatni [449/2003. tv. 21. \$, (3)-(4) bekezdések]. Végezetül a módosítás előírta, hogy a határidő, amin belül a jótállás érvényesíthető, attól az időponttól számítandó, amikor a vevő a dolog birtokába jutott [449/2003. tv. 22. \$(3)-(6) bekezdések]. A módosítás kiterjesztette mind a szavatosság, mind pedig a jótállás időtartamát bármely olyan időtartammal, amely folyamán a termék célnak megfelelő használata a meg nem felelés miatt nem volt lehetséges. A módosítás értelmében ez az időszak attól az időponttól számítandó, amikor 1. a fogyasztó a meg nem felelés tényét az eladó tudomására hozta, 2. a termék egy szervízszolgáltatónak került átadásra, illetve 3. bemutatásra, vagy 4. a fogyasztó a termék visszavételét írásban kérelmezte az eladótól. Bármely dolog esetében, amely más tartós felhasználású terméket helyettesít, új szavatossági határidő számítandó. A módosított jogszabály értelmében azon, szavatosság tárgyát képező termékek, amelyek a meg nem felelés okán a szavatosság időtartamának 10\%-át meghaladó időtartamra váltak használhatatlanná, a fogyasztó kérelmére kicserélendők.

A 2018. évi 353. törvény ${ }^{28}$ - amely a 2016. évi 9. kormányrendeletet hatályba léptette - a fentebb ismertetett módosításokat annyival egészítette ki, hogy előírta: az eladó egy korábbi termék kicserélése folytán a fogyasztónak

28 A termékek eladására és a hozzá füződő garanciákra vonatkozó 2003. évi 449. törvény módosítására vonatkozó 2016. évi 9. kormányrendelet jóváhagyásáról szóló 2018. évi 353. törvény [Legea 353/2018 privind aprobarea Ordonanței Guvernului nr. 9/2016 pentru modificarea și completarea Legii nr. 449/2003] a román Hivatalos Közlöny 4/2019.01.03. számában került közzétételre. 
átadott új termékért is szavatossággal tartozik (még akkor is, ha a kicserlés a jótállás érvényesítésével történt). Továbbá, a jótállási jegyet a fogyasztó számára érthető módon kell megfogalmazni, és az eladó a jótállásból fakadó bármely kötelezettségének kizárólag saját költségén köteles eleget tenni.

\section{A fogyasztó megítélése a román jogban}

A 449/2003. tv. a fogyasztó fogalmát jelenleg a következőképpen határozza meg: „(...) bármely természetes személy vagy természetes személyek egyesületekbe tömörült csoportja, amely saját kereskedelmi, ipari vagy termelési, kisipari vagy szabad foglalkozású tevékenységén kivül jár el” (21/1992. Korm. r. 2.\$2. pontja). Az egyesszám használata a mondat harmadik fordulatában helyes, mivel ez tükrözi a román nyelvü normaszöveget, amely a fogyasztót egyértelműen mint természetes személyt határozza meg. ${ }^{29}$ A fogyasztói egyesületekre való utalás csupán abból a célból történik, hogy lehetővé tegye az egyes fogyasztók kollektív képviseletét az ilyen egyesületek által, a 21/1992. Korm. r. 30-43. $\$$-ai rendelkezéseinek értelmében. A Ftvk. a fogyasztóra azonos meghatározást alkalmaz (lásd az Ftvk. Függelékének 13. pontját). Ennek megfelelően a román fogyasztóvédelmi jog terén, ami a fogyasztási cikkek eladását illeti, jogi személyek soha nem minösülhetnek fogyasztónak és fogyasztóvédelemben emiatt egyáltalán nem részesülhetnek. ${ }^{30}$ Továbbá, a román jog értelmében egyetlen jogi személy sem járhat el természetes személyi minőségben, mivel a román jog nem ismer a két személyiséget összevonó státuszt. ${ }^{31}$ Itt szükséges megjegyeznünk, hogy a fogyasztó meghatározása - már az eredeti formájában ${ }^{32}$ is, amelyet a 21/1992.

29 Lásd M. Iliescu: i. m., 2013, 587. Lásd továbbá R. D. Apan: Repere în definirea noțiunii de consumator. Pandectele Române, különszám 2008. március 31., elérhető: https://www.sintact.ro/\#/publication/151001161 (letöltés dátuma: 2020.02.15.) A szerző véleménye szerint, az alkalmazandó norma szövege kizárólag természetes személyekre vonatkozhat.

30 Korábban elszigetelten olyan vélemények is kifejezésre kerültek a jogi szakirodalomban, melyek szerint jogi személyek is fogyasztónak minősülhetnek. Lásd M. Iliescu: i. m., 2013, 588. 1. jegyzet és 589-591. Ezek valószínủleg a fogyasztó különböző jogszabályokban fellehető eltérő meghatározásaiból eredhettek, ahogyan azt Piperea említi. Utóbbi szerző korábban szintén hangoztatta a jogi személyek fogyasztóként kezelésének lehetőségét, de később elvetette e nézetet. G. Piperea: i. m., 10.

31 A jogi személyiséggel rendelkező társaságokat „A társaságokról szóló 1990. évi 31. törvény” szabályozza (legutóbb újra-közzétéve a román Hivatalos Közlöny 1066/2004.11.17. számában), míg a nem profitszerzési célú jogi személyek szabályozása Az egyesületekről és alapítványokról szóló 2000. évi 26. kormányrendeletben található (közzétéve a román Hivatalos Közlöny 39/2000.01.31. számában). További jogszabályok vonatkoznak más jogi személyekre (a szabad foglalkozások gyakorlására alapított társaságokra, a szövetkezetekre, a mezőgazdasági társulásokra stb.), de ezek közül egy sem minősíthető fogyasztónak.

32 További részletekért lásd a 13. és 18 . jegyzeteket fentebb. 
Korm. r. tartalmazott - mindenkor hangsúlyozta e státus és a természetes személyi mivolt összefüggéseit.

Azon természetes személyek, akik egyéni vállalkozás formájában folytatnak gazdasági tevékenységet, gazdálkodó szervezetnek (a 21/1992 Korm. r. szövege szerint), illetve eladónak (a 449/2003. tv. értelmében) minősülnek minden olyan esetben, amikor vállalkozói minőségükben járnak el. Problémát jelenthet azonban az olyan egyéni vállalkozók ${ }^{33}$ - például a kereskedelemben, a szolgáltatásokban, a szabad foglalkozásokban tevékenykedők - esete, akik fogyasztóként léphetnek fel egyes termékek megvételekor, miközben nem teljes mértékben vállalkozásuk tevékenységi körében járnak el, mert nem e tevékenységi körhöz füződően szerződnek. ${ }^{34}$ (Például egy ügyvéd, aki ugyanazon szerződésben egy nyomtatót vesz irodája számára és a nagyképernyőjü televíziókészüléket házi felhasználásra, egyazon eladótól.) A joggyakorlatban ilyen probléma azokban az esetekben is felmerült, amikor egy természetes személy fogyasztóvédelmi keresetet terjesztett elő olyan, jogi személy hasznára kötött, látszólag fogyasztói ügyletek vonatkozásában, amelynek keretén belül tevékenykedett. Kifejezetten a fogyasztói vétel területére vonatkozóan nem találtunk releváns román joggyakorlatot. Azonban egy nemrég lezárult ügyben, amelyben első fokon a Bihar Megyei Törvényszék, másodfokon pedig a Nagyváradi Ítélőtábla hozott döntést, e probléma fogyasztóvédelmi vonatkozásai felvetődtek (a 2000. évi 193. törvény ${ }^{35}$ által nyújtott védelem kérdésében). E határozatok bemutatását itt hasznosnak találjuk, ugyanis a 2000. évi 193. törvény fogyasztó-meghatározása alig különbözik ${ }^{36}$ attól, amelyet a 449/2003. tv. ad. Az ügyben két természetes személy terjesztett elő fogyasztóvédelemi igényt, akik közül az első egy kölcsönszerződés kereteiben kölcsönvevői minőségben szerepelt, míg a második a kölcsön törlesztésére biztosítékokat szolgáltatott, a két felperes közös tulajdonában álló

33 A gazdasági tevékenységek folytatására engedélyezett természetes személy státusát „Az engedélyezett természetes személyek, egyéni vállalkozások és családi vállalkozások általi gazdasági tevékenységek gyakorlására vonatkozó 2008. évi 44. sürgősségi kormányrendelet" [Ordonanța de urgență 44/2008 privind desfășurarea activităților economice de către persoanele fizice autorizate, intreprinderile individuale și întreprinderile familiale], hozta létre, amely a román Hivatalos Közlöny 328/2008.04.25. számában került közzétételre. Ez lehetővé teszi az erre engedéllyel rendelkező természetes személynek, hogy gazdasági tevékenységeket egyénileg (önfoglalkoztatottként) folytasson mint kerekedő vagy szolgáltató. Hasonló státuszok léteznek a szabad foglalkozásúak, például közjegyzők, ügyvédek, könyvelők, orvosok stb. esetében is.

34 Lásd M. Iliescu: i. m., 2013, 592-593.

35 A vállalkozók és fogyasztók között kötött szerződésekbe foglalt visszaélésszerű záradékokról szóló2000. évi 193. törvény [Legea 193/2000 privind clauzele abuzive din contractele încheiate între profesionişsti și consumatori] a román Hivatalos Közlöny 543/2012.08.03. számában került újra-közzétételre.

36 A 2000. évi 193. törvény által adott meghatározás azonos a 449/2003. tv. a 2007. évi 363. törvénnyel módosított definícióval. Lásd a 18. jegyzetet fentebb. 
ingatlanokon alapított jelzálog formájában. Az alperes pénzintézet állítása szerint a kölcsön kihelyezése a felperesek vállalkozói tevékenységének figyelembevételével történt, akik ingatlanfejlesztési és -értékesítési tevékenységet folytattak. A per folyamán született határozatok hivatkoztak az Európai Unió Bíróságának (EUB) a C-269/95 Benincasa, ${ }^{37}$ a C-464/01 Johann Gruber ${ }^{38}$ és a C-110/14 Horațiu Ovidiu Costea ${ }^{39}$ ügyben született határozataira.

$\mathrm{Az}$ elsőfokon eljáró bíróság a keresetet érdemben elutasította, ${ }^{40}$ azonban megállapította, hogy a felperesek keresetindítási joggal rendelkeztek, mivel fogyasztók. A másodfokú bíróság a keresetet, mint elfogadhatatlant utasította el, anélkül, hogy érdemi megalapozottságát megvizsgálta volna. Határozata indokolásában megállapította: a felperesek, bár fogyasztói hitelhez folyamodtak, illetve ilyen hitelhez nyújtottak biztosítékokat, nem rendelkeznek keresetindítási joggal, ugyanis bizonyítást nyert, hogy a hitel vállalkozói tevékenységük során került felhasználásra. A másodfokú bíróság érvelése figyelmen kívül hagyta az EUB újabb megállapításait, amelyek a C-464/01 Johann Gruber ítélet indokolásában olvashatók, előnyben részesítve a C-269/95 Benincasa ítéletben megfogalmazott érvelést, mikor megállapította: „kizárólag olyan szerzödések esetén, amelyek bármely vállalkozói tevékenységen kivül és attól, vagy annak céljától, függetlenül, a magánszemély személyes fogyasztási szükségleteinek kielégitése egyedüli céljával kerültek megkötésre, képezhetik részét annak a különleges rendszernek, amely a fogyasztóvédelem kérdésére alkalmazandó, mig ilyen védelem nem indokolt olyan szerzödés esetében, melynek célja vállalkozási tevékenység (...).’¹

A Legfelsőbb Semmítő- és Ítélőszék egyik nemrég közzétett határozatában ${ }^{42}$ hasonló következtetéseket fogalmaz meg. Szükséges megjegyeznünk, hogy az EUB a C-464/01 Johann Gruber ügyben hozotthatározatában megállapította: a fogyasztóvédelmi normák csupán azokban az esetekben nyújtanak védelmet, amikor a szerződés vállalkozási

37 C-269/95. sz. Francesco Benincasa v. Dentalkit Srl ügyben 1997. július 3-án hozott ítélet (ECLI:EU:C:1997:337).

38 C- 464/01. sz. Johann Gruber v. Bay Wa AG ügyben 2005. január 20-án hozott ítélet (ECLI:EU:C:2005:32).

39 C-110/14. sz. Horațiu Ovidiu Costea v. SC Volksbank România SA ügyben 2015. szeptember 3-án hozott ítélet (ECLI:EU:C:2015:538).

40 Bihar Megyei Törvényszék, 2018. július 5-i 166/2018. sz. polgári határozata (https://www.sintact.ro, letöltés dátuma: 2020.02.12.)

41 Nagyváradi Ítélőtábla, 2019. május 7-i 158/2019. sz. polgári határozata (https://www.sintact.ro, letöltés ideje: 2020.02.12.)

42 Legfelsőbb Semmítő- és Ítélőszék, Második Polgári Kollégium, 2018. február 2-i 479/2018. sz. határozata (http://www.scj.ro, letöltés ideje: 2020.02.12.) 
tartalma „elhanyagolható”ł3 (vagyis a szerződés nem kell, hogy teljesen független legyen a vállalkozási tevékenységtől, ahogyan az a román ítélkezési gyakorlatban megállapítást nyert). A román jogalkotó nem határozott meg semmilyen mennyiségi vagy minőségi kritériumot, az EUB C-464/01, Johann Gruber és C-110/14, Horațiu Ovidiu Costea ügyekben született határozatainak megfelelő megoldás átültetésére, így a természetes személy fogyasztóvá vagy vállalkozóvá minősítése eseti alapon valósul meg a bíróságok által. A Legfelsőbb Semmítő- és Ítélőszék nem hozott létre ${ }^{44}$ általános, objektív kritériumrendszert e probléma megoldására. Emiatt azt a következtetést kell levonnunk, hogy bármely természetes személy, akinek vállalkozói tevékenysége az RPtk. 3. \$-ának értelmében, ${ }^{45}$ egy másik személlyel létesített szerződéses jogviszony keretein belül bármilyen csekély mértékben is érvényre jut, nem minősülhet fogyasztónak, még abban az esetben sem, ha e vállalkozói minőség az ügyletet tekintve elhanyagolható. E következtetéseket azon fenntartással kell megfogalmaznunk, hogy a fenti joggyakorlat kizárólag a visszaélésszerű szerződéses záradékokra vonatkozó fogyasztóvédelmi keresetek tekintetében alakult ki, így azok a bíróságok, amelyeknek a jótállás vagy a szavatosság fogyasztóvédelmi vonatkozású normáit kell a jövőben alkalmazniuk, attól eltérően is határozhatnak majd.

\section{A szerződésszerüség vizsgálata és terjedelme a belső jogban és a joggyakorlatban}

Az 1999/44/EK irányelv 2. cikkének rendelkezései a román belső jogba a 449/2003. tv. II. fejezetében kerültek átültetésre [a 449/2003. tv. 5-8 \$-ai, ahol az 5. $\$$ az irányelv 2 . cikke (1) és (2) bekezdései szövegével analóg, míg a törvény minden további $\$$-a az irányelv 2 . cikke további egy-egy bekezdésének felel meg]. A román norma e téren az irányelv többé-kevésbé szöveghü fordítása, azzal a legjelentősebb eltéréssel, hogy a fogyasztási cikk fogalma helyett termék ${ }^{46}$

43 C- 464/01, Johann Gruber ügyben született itélet, 39. és 41. ítéletpontok.

44 A román Legfelsőbb Semmítő- és Ítélőszék a belső jogban előírt előzetes döntéshozatal iránt megkeresésre került annak érdekében, hogy kötelező erővel határozza meg, mely kritériumok alapján minősíthető egy személy fogyasztónak, amikor e minősítés vitatott. Az erre irányuló megkeresést formai okokra hivatkozva visszautasította. Mindazonáltal visszautasító határozatában (Legfelsőbb Semmítő- és Ítélőszék 2018. június 4-i 37/2018. sz. határozata előzetes döntéshozatali kérdésről, 53. bekezdés) a Semmítőszék elismerte, hogy e kérdéskörben a joggyakorlat nem egyhangú (http://www.scj.ro, letöltés ideje: 2020.02.12.).

45 Következtetésünket a Legfelsőbb Semmítő- és Ítélőszék gyakorlatára alapozzuk, amelyet fentebb ismertettünk, valamint e bíróság Második Polgári Kollégiumának 2016. március 2-i 441/2016. és 2017. január 26-i 115/2017. sz. határozataira (http://www.scj.ro, letöltés ideje: 2020.02.19.)

46 A termékek meghatározása a 449/2003. tv. 2. \$-ának b) pontja értelmében mozgatható testi tárgyak, amelyek 
áll. Emiatt a megfelelőség fogyasztási célú adásvételi szerződésekben minden szempontból azonos feltételek szerint kerül megállapításra, mint azok melyeket az 1999/44/EK irányelv tartalmaz. A RPtk. 1716. \$-a is hasonló rendelkezéseket ír elő, bár ezek a fogyasztási célú adásvétel esetében nem alkalmazandók. A termékek megfelelőnek tekintendők a román jog szerint (449/2003. tv. 5. §) amennyiben: ${ }^{47}$

- megfelelnek az eladó által nyújtott leírásnak és azonos tulajdonságokkal, illetve jellemzőkkel rendelkeznek, mint az eladó által bemutatott minta vagy modell,

- megfelelnek bármely kifejezett célnak, amelyet a fogyasztó igényelt, amennyiben e célt az eladó tudomására hozta és azt az eladó elfogadta, legkésőbb a szerződéskötés pillanatában,

- megfelelnek azoknak a céloknak, amelyekre azonos természetű dolgok szokványosan felhasználásra kerülnek,

- szem előtt tartva az eladó, a gyártó, vagy ezek bármelyikének képviselője által azonos típusú termékek jellemzőire tett nyilvános nyilatkozatait, - kiemelten akkor, ha ezek reklámokban vagy a termék címkéjén szerepelnek - a termék azokkal a szokványos minőségi és müködési jellemzőkkel rendelkezik, amelyeket a fogyasztó észszerűen elvárhat.

A román jogi szakirodalom, amikor a megfelelés fogalmát kísérelte meg a polgári jog fogalmaival összefüggésbe hozni, megállapította, hogy a megfelelés abban az esetben létezik, amikor a termék a fogyasztó számára átadásra került a szerződésnek megfelelően, azt nem sújtják rejtett hibák, a fogyasztó nincs tévedésben annak tartalmát, vagy anyagát illetően, és a fogyasztó nem került megtévesztésre az eladó által tett csalárd nyilatkozatok, vagy az általa elkövetett cselekmények, illetve mulasztások miatt. ${ }^{48}$ Itt szükséges megjegyezni, hogy a célnak való megfelelés - még abban az esetben sem, ha e célt a fogyasztó

végsö felhasználási célja a fogyasztás, vagy más, egy vagy több egyén általi felhasználás. Az elkobzás után eladott dolgok, a kényszervégrehajtás folyamán vagy bírósági határozat alapján értékesített dolgok, a víz, valamint a nem különálló csomagolásban, vagy elöre meghatározott mennyiségben értékesített gázhalmazállapotú anyagok, illetve az elektromos áram nem esnek a 449/2003. tv. tárgyi hatálya alá. Emiatt a törvény tárgyi hatálya az ingatlanokra és a szolgáltatásokra nem terjed ki. Lásd I.-F. Popa, i. m., 2005, 162. Egyes szerzők úgy tekintik, hogy az épületekbe beépített építőanyagok termékeknek minősíthetők (E. M. Minea: Incidența reglementărilor vizând protecția consumatorilor în domeniul construcțiilor de locuințe. Revista Română de Drept al Afacerilor, 2010/9. 27.), bár ezen értelmezés téves.

47 A. N. Gheorghe, C. Spasici, D. S. Arjoca: Dreptul consumației. Editura Hamangiu, București, 2012, 219.

48 I.-F. Popa, i. m., 2005, 166. 
kifejezetten megjelölte, vagy azt az eladó hallgatólagosan feltételezte - nem foglalható bele a hagyományos polgári jogi értelmezési keretbe.

A 449/2003. tv. (8. \$) rendelkezései értelmében a teljesítés abban az esetben sem szerződésszerü, ha a megfeleléshez felsorolt feltételek teljesülnek ugyan, de a termék szakszerütlen telepítésének (összeszerelésének) tulajdoníthatóan nem felel meg a szerződés explicit, illetve implicit tartalmának. Ebben az esetben lényegtelen, hogy a telepítést az eladó, vagy az eladó helyett, de annak megbízásából eljáró harmadik személy végezte. Ugyanez alkalmazandó a fogyasztó által elvégzett szakszerütlen telepítésre is, utóbbi esetben akkor, ha ennek okát a fogyasztónak adott téves utasítások adják. ${ }^{49} \mathrm{~A}$ jogszabály szövege nem tartalmaz külön rendelkezést, amely szűkítené azon (harmadik) személyek körét, akiknek a téves utasítás tulajdonítható, emiatt a fogyasztó a megfelelés hiányára abban az esetben is hivatkozhat, ha az összeállítási, illetve telepítési utasítások a gyártótól vagy az eladó nevében eljáró harmadik személytől származnak.

A szavatossági, vagy jótállási igény semmilyen olyan esetben nem érvényesíthető, amikor a szerződéskötés pillanatában a fogyasztó tudta, vagy tudnia kellett, hogy a termék nem megfelelö. A fogyasztó abban az esetben sem érvényesítheti a szavatosságot vagy jótállást, ha a termék meg nem felelése a fogyasztó által szolgáltatott alapanyagoknak tulajdonítható. Végezetül, az említett formában bekövetkező fogyasztói jogvédelem akkor sem lehetséges, ha az eladó bizonyítja, hogy a nyilatkozat, amelynek alapján a fogyasztó jótállási követelését érvényesíteni szeretné, számára nem volt - és nem is lehetett - ismert, vagy e nyilatkozatot a szerződéskötés pillanatában az eladó már visszavonta. Azonos kimentési indok áll fenn abban az esetben is, amikor bizonyítást nyer, hogy a nyilatkozat nem bírt jelentőséggel a fogyasztó szerződéskötési akaratának kialakításában (449/2003. tv. 6-7. \$-ai). A megfelelés hiánya a 449/2003. tv. értelmében abban az esetben sem felhívható, amikor a fogyasztó soha nem lépett a termék birtokába. Ezekben az esetekben a fogyasztó számára az RPtk. rendelkezései szerinti jogvédelmi eszközök állnak rendelkezésre (a teljesítés kikényszerítése, a szerződés felbontása, a szerződéstől történő elállás). ${ }^{50}$

Ami a termékdokumentációra vonatkozó belső szabályokat illeti, a 449/2003. tv. ezek tartalmára nézve nem tartalmazérdemleges rendelkezéseket. Ilyen szabályok

49 F. Tudoriu, C. A. Popârțac: Drepturile consumatorului. O provocare pentru afaceri, Universul Juridic, București, 2013, 158.

50 E. Mihai: Contractul de credit pentru consum în viziunea Ordonanței de urgență a Guvernului nr. 50/2010. Revista Română de Drept al Afacerilor, 2012/5. 43. Egyetértünk ezzel a következtetéssel a fogyasztói jogok terén, amelyek föszabály szerint nincsenek alávetve az RPtk. normáinak, de ezt nem tekintjük általános 
a Ftvk. tartalmában lelhetők fel (38-63. \$-ok). E normák legtöbbje a fogyasztók tájékoztatására vonatkozik, illetve a termékek címkézésére. A fogyasztónak ezek értelmében joga van a termék kockázataira (Ftvk. 48. §) és „lényeges jellemzőire” (Ftvk. 45. \$) nézve teljeskörü tájékoztatásban részesülni, annak érdekében, hogy az illető vétel kapcsán a megfelelő információk birtokában (a román jogszöveg szerint „racionális” módon) dönthessen. A szükséges információt tartalmazhatja a termék címkéje, csomagolása, technikai információkat tartalmazó más anyagok, vagy a felhasználói útmutató (Ftvk. 47. \$). A fogyasztó egészsége és biztonsága védelmében közölt információkat a román norma értelmében lehetőség szerint könnyen értelmezhető, a nemzetközi gyakorlatban használatos grafikus szimbólumok segítségével ajánlatos közölni (Ftvk. 46. \$). A tartós felhasználású termékek esetében, amikor ezt jogszabály kifejezett rendelkezése előírja, kötelező a termékkel együtt a fogyasztó számára a jótállási jegy, a termék jelentős technikai információinak leírása, valamint a gyártó által biztosított telepítési, összeállítási, használati és karbantartási útmutató, valamint a megfelelési tanúsítvány átadása is (Ftvk. 53. \$). Az itt felsorolt anyagokat román nyelven szükséges a fogyasztó rendelkezésére bocsátani, anélkül, hogy a román nyelv mellett más nyelvek használata korlátozva lenne (Ftvk. 55. \$). Erre irányuló igény esetén a termék használatát a vételt követően (és a lehetőségekhez mérten) az eladó a felhasználónak gyakorlatban kell, hogy bemutassa (Ftvk. 59. \$).

A román jog nem szabályozza más, általános normák útján a termékek értékesítésének kötelező feltételeit, és nem írja elő (de nem is tiltja) ilyen feltételek szakmai szervezetek általi kidolgozását, ezzel lehetővé téve az önszabályozást egyes gazdasági szereplők esetében.

\section{A szavatossági és jótállási igény érvényesítésének szabályai}

A szavatosság vagy jótállás érvényesítése során a fogyasztó a termék megfelelőségének helyreállítására tarthat igényt. Ezen intézkedéseket a 449/2003. tv. 10. \$-a nevesíti. A fogyasztó kérheti: a termék 1. kijavítását, 2. kicserélését, 3. a vételár visszafizetését, vagy - esettől függően - annak csökkentését arányosan a meg nem felelés mértékével. Ezen intézkedések bármelyikét a fogyasztó ingyenesen kérheti. Az 1999/44/EK irányelv 3. cikkének rendelkezéseivel

érvényűnek. A román jogi szakirodalom általában úgy értékeli, hogy a szerződésszerủ teljesítés egyik feltétele a vevő a megvett dolog birtokába helyezése. Lásd I.-F. Popa: Conformitatea lucrului vândut - Între rigiditate tradițională și funcționalism. Revista Română de Drept Privat, 2009/1. 136-138. 
összhangban - amelyeket a román jogalkotó a belső jogba lényegében szó szerint ültetett át - a felek között keletkezett ellenkező egyezség hiányában, a fogyasztó elsödleges intézkedésként a termék kijavítását vagy kicserélését kérelmezheti, és csupán mint szubszidiárius intézkedést kérheti a vételár lecsökkentését vagy visszafizetését, azokban az esetekben amikor a kijavítás vagy a kicserélés lehetetlen, illetve aránytalan intézkedés lenne. A termék kijavítására vagy kicserélésére vonatkozó észszerü időtartam az 1999/44/EK irányelv 3. cikkének (3) bekezdésébe foglalt kritériumát a román jogalkotó számszerüsítette a 449/2003. tv. 11. \$-ának (4) bekezdésében. Eszerint az intézkedések foganatosítása maximum 15 naptári napon belül kell, hogy bekövetkezzen attól az időponttól számítva, amikor a fogyasztó az eladót a termék nem megfelelő mivoltáról értesítette, vagy a terméket az eladónak, illetve az eladó által e célból meghatalmazott más személynek okirattal igazolható módon átadta. További járulékos jogszabályi előírásként, amely az átültetendő irányelvi normákat bővíti, a 449/2003. tv. 11. \-ának (5) bekezdése előírja, hogy a javítás során csupán új alkatrészek használhatók. Amennyiben a termék helyettesítésre kerül, az eladó ugyanazon jótállás biztosítására köteles a helyettesítő termék vonatkozásában, mint az eredeti termék esetén, azonban ennek jogalapja ope legis a törvényben előírt szavatosság lesz [449/2003. tv. 11. $\$(6)$ bekezdés].

Némileg eltérően az 1999/44/EK irányelv 3. cikkének (5) bekezdésében foglaltrendelkezésektől, a 449/2003. tv. 13. \$-a - amely ezen irányelvi rendelkezések átültetésére hivatott - nem taxatív módon sorolja fel azokat a helyzeteket, amikor a fogyasztó kérheti az ár csökkentését, vagy elállhat a szerződéstől. A felsorolt helyzetek, ${ }^{51}$ - amelyek majdnem azonosak az 1999/44/ EK irányelv 3. cikkének (5) bekezdésében foglaltakkal - emiatt csupán példálózó felsorolás elemeinek minősíthetők. Az 1999/44/EK irányelv vélhetően téves román fordításából adódóan a 449/2003. tv. 13. \$-ának a) pontja értelmében az ár csökkentése nem csupán abban az esetben lehetséges, amikor „A fogyasztó (...) nem jogosult sem a fogyasztási cikk kijavitására, sem a kicserélésére” az 1999/44/EK irányelv értelmében, hanem minden olyan esetben, amikor „számára a kijavítás vagy kicserélés nem kedvez" (vagyis olyan esetekben is, amikor a kijavítás vagy kicserélés számára már nem hasznos). A fogyasztó nem állhat el a szerződéstől, ha

51 A 449/2003. tv. három ilyen helyzetet sorol fel annak 13. \$-ában: 1. ha a fogyasztó számára a dolog kijavítása vagy kicserélése nem kedvező, 2 . ha az eladó a terméket nem javította ki vagy nem cserélte ki észszerủ időn belül, és 3 . ha az eladó a kijavítást vagy kicserélést nem olyan módon valósította meg, hogy ezzel a fogyasztó számára okozott jelentős kellemetlenséget orvosolja. Emiatt a fogyasztó csupán azokban az esetekben állhat el a szerződéstől, amikor más módon jogsérelme nem orvosolható, vagy a jogsérelem elhárításának eszköze e célt nem teljesítette. N. A. Daghie: Aspecte teoretice și practice privind condițiile cerute pentru admisibilitatea rezoluțiunii judiciare. Revista Română de Drept privat, 2009/6. 55-56. 
a meg nem felelés csekély (449/2003. tv. 14. \$). A meg nem felelés mértékének megállapítása a konkrét esetekben elengedhetetlen. E kérdésben a román szakirodalomban megfogalmazódott az a nézet, miszerint a szerződésszerü teljesítés elmaradása a fogyasztóvédelem terén szélesebb jelentéstartalommal veendő figyelembe, mint általában, másfajtaszerződések esetén. E fogalom ilyenkor tartalmazza „a szerzödésszerü teljesités elmaradásának felmérésére alkalmazandó komplex kritériumokat (...), szem elött tartva az adásvételi szerzödésnek való megfelelést és a fogyasztó jogos elvárásait a szerzódés tartalmához viszonyitva. "'2 E nézet szerint a szerzödésszerü teljesités fogalma magában foglalná a termék szerzödésszerü átadását ${ }^{53}$ és az érte nyújtandó szavatosságot rejtett hibák, illetve a termék anyaga tekintetében fennálló esetleges fogyasztói tévedés esetén. ${ }^{54}$

Amennyiben az eladó jótállást ${ }^{55}$ (a román szaknyelvben törvényes garanciát) is ajánl, (vagyis olyan szerződéses garanciát vállal, amely a jótállási jegy tartalmának, vagy a termékre vonatkozó reklámanyagok állításainak való megfelelést biztosítja) az eladót e jótállás kötelezi. Semmilyen, a felek között kötött egyezség (ideértve a jótállási feltételeket is) nem csökkentheti vagy hatálytalaníthatja a 449/2003. tv. által az eladó terhére rótt kötelezettségeket, amennyiben annak megkötése a megfelelés hiányának a vevő általi észlelése és az eladó iránti közlése előtt történt [449/2003. tv. 22. \$ (1) bekezdés]. Az ilyen egyezség semmis, kivéve, amikor tárgya használt termékek esetén a törvényben előírt jótállási határidő lecsökkentése, és a felek által megszabott határidő egy évnél nem rövidebb. Az eladó által nyújtott jótállás ilyenkor a törvényben elöírt szavatosság mértékét csökkentheti. Az eladó kedvezőbb feltételek mellett vállalhat szerződéses természetü, nem-fogyasztói jótállást is: a vevő számára többletköltséget feltételező módon további, a 449/2003. törvényben nem elöírt intézkedésekben megnyilvánuló jótállás biztosítására is kötelezheti magát. E többletköltség ellenében nyújtott jótállás már nem a 449/2003. tv. által szabályozott (definíciójából eredően ingyenes) „kereskedelmi” jótállásnak minősül majd, emiatt arra a 449/2003. tv. tárgyi hatálya nem terjed ki.

52 V. Terzea: Neexecutarea obligațiilor contractuale. Revista Română de Drept Privat, 2018/6. 522. Más szerzők kettős megfelelésröl beszélnek, egyrészt az adásvételi szerződéssel (objektív kritérium), másrészt a fogyasztó elvárásaival (szubjektív kritérium) szemben. I.-F. Popa, i. m., 2005, 165-168.

53 Nem értünk egyet ezzel a következtetéssel. Ahogyan azt fentebb már említettük, a megfelelés hiánya csupán abban az esetben hozható fel, amikor a fogyasztó a termék birtokába lépett, ugyanis e fogyasztó a meg nem felelésre csupán annak általa történő megállapítását követően hivatkozhat.

54 Lásd V. Terzea: i. m., 522-523.

55 Lásd a 26. jegyzetet fentebb. 
A 449/2003. tv. előírásai megfelelnek az EUB Weber és Putz ügyekben ${ }^{56}$ kimunkált gyakorlatának, köszönhetően az Egyes fogyasztóvédelmi vonatkozású jogszabályok módositására és kiegészitésére vonatkozó 2008. évi 174. sürgösségi kormányrendelet által véghez vitt módosításoknak. A rendelet módosította a 449/2003. tv. 12. \$-ának rendelkezéseit, annak érdekében, hogy biztosítsa, a megfelelés helyreállításának - a fogyasztó szempontjából - ingyenes jellegét annak minden elemére nézve, ideértve a „(..) postázás, fuvarozás, rakodás, diagnosztika, szakértöi véleményezés, eltávolitás, visszaépités, munkadijak, anyagok és csomagolás" költségeit. A felek nem köthetik ki a költségek megosztásának semmilyen olyan formáját, amely e szabálytól a fogyasztó számára hátrányos módon eltérne, ugyanis ez a de minimis kötelezettségeket elöíró szavatosság keretein belül került szabályozásra. Így a termék eltávolításának és visszaépítésének költségeit az eladó viseli attól függetlenül, hogy a termék beépítése az eladó, a vevő, vagy egy erre engedéllyel rendelkező harmadik személy által történt. Emiatt a román norma nem tér el a Weber és Putz ügyekben született határozat rendelkező részébenadott első választól.

A Weber és Putz határozat rendelkező részében megfogalmazott második következtetés szintén összhangban van a román joggal. A 449/2003. tv. 11. \$-ának (2) bekezdése alapján az eladó abban az esetben minősítheti a termék kijavítására irányuló egyes intézkedéseket aránytalannak, ha azok számára észszerűtlenül magas költségeket feltételeznek, bármely más lehetséges, a megfelelés helyreállitását célzó intézkedéshez képest, figyelembe véve többek között a termék értékét abban az esetben, ha az a szerződésnek megfelelne, illetve a meg nem felelés jelentőségét is. Emiatt, ha a kicserélés költsége az eladó számára aránytalan lenne, más intézkedésekkel szükséges a megfelelést helyreállítani. A Weber és Putz ügyekben született határozat második következtetésének premisszája, hogy a kicserélés az egyedüli lehetséges helyreállítási intézkedés. A román norma által a különböző helyreállítási intézkedések összehasonlításának kritériuma abból a premisszából indul ki, hogy legalább két helyreállítási intézkedésnek lehetségesnek kell lennie. Emiatt az eladó nem hivatkozhat a kicserélés költségeinek aránytalanságára abban az esetben, ha a kicserélés a megfelelés helyreállítására lehetséges egyedüli intézkedés lenne.

56 C-65/09. sz. Gebr. Weber GmbH v. Jürgen Wittmer és C-87/09 Ingrid Putz v. Medianess Electronics GmbH egyesített ügyekben 2011. június 16-án hozott ítélet (ECLI:EU:C:2011:396). A Weber és Putz ügyekben hozott határozat kommentárjáért román nyelven lásd A. Groza: Din jurisprudența recentă a Curții de Justiție a Uniunii Europene. Revista Forumul Judecătorilor, 2011/4. 232-235. 


\section{A szavatossági és jótállási igény érvényesítésére nyitva álló határidők a román jogban}

\section{1. Általános szabályok}

A szavatosság és jótállás érvényesítésére vonatkozó határidőket a 449/2003. tv. szabályozza, annak V. fejezetében (16-18. \$-ok). ${ }^{57} \mathrm{Az}$ eladóval szemben szavatosság akkor érvényesíthető, ha a megfelelés hiánya a termék a vevőnek történő átadásától számított kétéves határidőn belül válik észlelhetővé (449/2003. tv. 16. \$). A termék átadása alatt az a pillanat értendő, amikortól a fogyasztó a termék birtokába lép [449/2003. tv. 22. \$(6) bekezdés I. fordulat]. E szabály érvényesül a jótállás esetén is, ha a felek egyezségükkel másként (a fogyasztónak kedvezőbb módon) nem rendelkeznek. A szavatossági idő csökkentése nem lehetséges a jótállás szerződéses szabályainak keretein belül, ${ }^{58}$ kivéve, amennyiben a szerződés használt termékre vonatkozik, és a lecsökkentett határidő még ebben az esetben sem lehet rövidebb egy évnél [449/2003. tv. 22. \$ (2) bekezdés]. ${ }^{59}$ E rendelkezések megfelelnek az 1999/44/EK irányelv 5. cikk (1) bekezdésének (első fordulat). A kétéves határidő időtartama ope legis lecsökken a termék átlagos használati idejére, abban az esetben, ha az a kétéves időtartamnál rövidebb lenne (449/2003. tv. $16^{2}$. \$). ${ }^{60}$

A határidő az RPtk. 2552. \$-ában előírt, a határidők számítására általánosan vonatkozó normák szerint számítandó. Ez ugyanazon hónap ugyanazon napján telik le, amikor a termék átadása a fogyasztó számára bekövetkezett, a kétéves időtartam elteltével. Az RPtk. rejtett hibákból eredő nem megfelelő teljesítésre az általános adásvételi szerződések esetében a fogyasztóvédelmi szavatosságtól kifejezetten elkülönülő (eszköz-) szavatosságot biztosít (RPtk. 1707-1715 §-ai). Felvetődik tehát a kérdés: a szavatossági időtartam kezdetének meghatározására fogyasztói szerződések esetében alkalmazható-e az RPtk. normáiba foglalt különös szabály [melynek értelmében a határidő számítása egy évvel az eladott dolog vevőnek való átadását követően ope legis megkezdődik, az RPtk. 2531. $\$$ (1) bekezdésének a) pontja szerint, amennyiben a rejtett hiba felfedezésére ennél hamarabb nem került sor]? Ez álláspontunk szerint nem lehetséges, mivel

57 A határidők természetének részletes elemzéséhez lásd I.-F. Popa: Regimul juridic al termenelor în materia garanției de conformitate. Revista Română de Drept Privat, 2007/4.

58 A határidő kógens természetü. I.-F. Popa: i. m., 2007.

59 Lásd A. N. Gheorghe, C. Spasici, D. S. Arjoca: i. m., 222. F. Tudoriu, C. A. Popârțac:. i. m., 158-159.

60 A. N. Gheorghe, C. Spasici, D. S. Arjoca: i. m., 221. 
a 449/2003. tv. rendelkezései az RPtk. rendelkezéseivel szemben elsőbbséggel alkalmazandók fogyasztói eladások esetében, az RPtk. 2531. \$ (5) bekezdése értelmében. E megoldás összeegyeztethető az 1999/44/EK irányelv 5. cikkének (1) bekezdésével is.

A kétéves határidő természetét illetően, amelyen belül a meg nem felelés felhozható (amely a termék esetlegesen két évet meghaladó átlagos használati idejére a 449/2003. tv. 161. \$-ának értelmében ope legis meghosszabbodik), ezt a román joggyakorlat még nem határozta meg. Ha a határidő elévülési jellegü határidőnek minősülne, ez több okból is felfüggeszthető lenne, illetve számítása újrakezdődhetne (többek között abban az esetben, ha az eladó a szavatosság vagy jótállás iránti késedelmes kérelmet akár implicit módon és akár csak részben is elfogadja). Ezzel az értelmezéssel nem értünk egyet, ${ }^{61}$ mivel a 449/2003. tv. 16. \$-ának rendelkezései - amelyek az 1999/44/EK irányelv 5. cikke (1) bekezdésének felelnek meg - az eladó felelősségére, és nem a vele szembeni keresetindításra vonatkoznak. Ugyanezen következtetések arra a kéthónapos időtartamra is mutatis mutandis érvényesek, amelyen belül a fogyasztónak az eladót tájékoztatnia kell meg nem felelésről. ${ }^{62}$ Ebben az értelemben, a határidő nem elévülési, hanem jogvesztő (záros) jellegű, letelte után a vevő nem érvényesítheti igényét. A jogvesztő határidőkre az RPtk. sokkal szigorúbb szabályokat alkalmaz mind felfüggesztésük, mind pedig azok számításának újrakezdése esetén (RPtk. 2545-2550. \$-ai). Jogvesztő határidők főszabály szerint nem függeszthetők fel, és számításuk nem kezdődhet újra [RPtk. 2548. \$, (1) bekezdés] a vis maior által indokolt esetek kivételével, amelynek e határidőket is felfüggesztik.

A szavatosság és jótállás érvényesítésére megszabott határidő ipso iure meghosszabbodik azzal az időtartammal, amely alatt a termék működésképtelen, vagy rendetetésének betöltésére alkalmatlan volt a megfelelőség hiánya miatt. Ez az időtartam attól a pillanattól számítandó, amikortól az eladó tájékoztatása a meg nem felelésről megtörtént (abban az esetben is, ha a közlés tényét a felek írásban nem rögzítették), vagy amikortól a vevő a terméket az eladónak, vagy más, az eladó által a termék kijavítására meghatalmazott szervnek vagy személynek átadta, illetve attól a pillanattól, amikor a vevő írásban kérte az eladótól a termék elszállítását [449/2003. tv. 22. \$(3) bekezdés].

61 Ebben az értelemben lásd I.-F. Popa: i. m., 2007.

62 Valamelyest ellentétes értelemben lásd I.-F. Popa: i. m., 2007. 
Csupán a tartós felhasználású termékek esetében következik be a szavatossági és jótállási határidők törvényi kiterjesztése kicserélés esetén, ${ }^{63}$ és csupán akkor, amikor velük ekvivalens, új termékekkel kerültek kicserélésre [449/2003. tv. 22. $\$(4)$ bekezdés]. A kiterjesztett határidő a csereterméknek a vevő számára történő átadásától számítandó. A 449/2003. tv. nem írja elő a határidő kiterjesztését a termék kijavítása esetén. E helyzetet azonban a következőképpen teszi kedvezőbbé a jogalkotó. Amikor egy tartós felhasználású termék meg nem felelését a szavatossági időn belül észlelik, és a termék a szavatossági időtartamot legkevesebb 10\%-kal meghaladó ideig használhatatlan volt, illetve kijavítása nem lehetséges, az eladónak azt ki kell cserélnie, vagy a vételárat vissza kell fizetnie a fogyasztó számára [449/2003. tv. 22. \$(5) bekezdés].

\subsection{Rejtett hibák}

A fogyasztók kérhetik a rendeltetésszerű használatra alkalmatlanná vált termékek „helyreállítását” (tehát kijavítását), vagy kicserélését olyan rejtett hibák ${ }^{64}$ esetén, amelyek a termék átlagos használati ideje alatt kerültek észlelésre, amennyiben az átlagos használati idő a szavatosság kétéves időtartamát meghaladná (449/2003. tv. 161. \$). Ilyenkor a fogyasztó csupán abban az esetben fordulhat kérelemmel az eladóhoz, ha számára jogszabály erre lehetőséget biztosít (a 449/2003. tv. megfogalmazása szerint), esetünkben az RPtk. rejtett hibákra vonatkozó szabályai szerint. E hibák elhárításának módozatait a törvény a termék kijavítására vagy kicserélésére korlátozza. Rejtett hibák esetén a kétéves szavatossági idő attól az időponttól számítandó, amikor az ügyben megkeresett semleges szakértő (például az igazságügyi szakértői testület tagja) a hibára vonatkozó szakértői véleményét ismertette [21/1992 Korm. r. 13. \$ (2) bekezdés]. E jogszabály a szakirodalom ${ }^{65}$ vélekedése szerint különös norma a 449/2003. tv. rendelkezéseihez képest, ezért ebben az esetben a 449/2003. évi tv. határidő-számítási mechanizmusát felülírja.

63 A tartós fogyasztási cikkek fogalmát a 449/2003. tv. 2. \$-ának i) pontja határozza meg, melynek értelmében ilyenek a „komplex termékek, amelyeket alkatrészek és alegységek alkotnak, amelyek tervezése, felépitése olyan jellegü, hogy ezek adott átlagos ideig felhasználhatók legyenek, és melyek esetében adott a javitás és a karbantartás lehetösége". (A szöveg a román normaszöveg pontos fordítása, a közelebbről meg nem határozott átlagos használati idő a jogalkotó megfogalmazása.)

64 E hibák minden kritériumnak meg kell, hogy feleljenek, amelyeket a jogszabály elöír annak érdekében, hogy rejtettnek minősülhessenek. F. Tudoriu, C. A. Popârțac: i. m., 161.

65 I.-F. Popa: i. m., 2007. 


\subsection{Az eladó tájékoztatása}

A 449/2003. tv. rendelkezései (17. \$) két hónapos határidőt írnak elő, amelyen belül a fogyasztónak tájékoztatnia kell az eladót a megfelelés hiányáról, annak érdekében, hogy élhessen a szavatosság vagy a jótállás által biztosított jogokkal. E rendelkezés az 1999/44/EK irányelv 5. cikkének (2) bekezdésén alapul, amely e határidő rögzítését kifejezetten megengedi a tagállamok számára. Az eladó e határidőn belüli tájékoztatásának elmulasztása a fogyasztó szavatosságból vagy jótállásból eredőjogainak elvesztésével jár (utóbbi esetben a felek kedvezőbb szerződéses egyezsége hiányában).

\section{A szavatosságra és jótállásra vonatkozó különös szabályok}

A fogyasztási termékekre nyújtandó szavatosságra és jótállásra vonatkozó részletes szabályok mind a fogyasztók, mind pedig az eladók számára egy sor kötelezettséget írnak elő. Ezek különbözhetnek annak függvényében, hogy a garancia szavatosság formáját ölti, vagy a termékre az eladó jótállást (is) biztosított. A fogyasztó minden esetben hivatkozhat a szavatosságra, és emellett, ha jótállásra is jogosult, e garanciát is érvényesítheti, anélkül, hogy a szavatosságról lemondana. A reklámokban a megfelelésre vonatkozóan tett állítások is jótállást keletkeztetnek. A vevő kiterjesztett jótállásban is részesülhet, ha az eladó külön fizetési kötelezettség ellenében számára ilyet biztosít, ezt azonban a fogyasztóvédelmi normák nem szabályozzák.

A jótállási jegyet, amely a szavatosság és jótállás feltételeit rögzíti, a fogyasztó számára írásban vagy más tartós médiumon (például kompaktlemezen) kell átadni, de fosszabály szerint csupán azokban az esetekben, ha erre a fogyasztó igényt tart [449/2003. tv. 21. \$(1) bekezdés]. Az eladó azonban köteles a tartós felhasználású termékek vevőinek minden esetben írásban jótállási jegyet biztosítani. Az adásvételi szerződés, a jótállási jegy, illetve bármilyen dokumentáció, amely a termékre vonatkozik, román nyelven szerkesztendő [21/1992. Korm. r. 20. $\$(5)$ bekezdés, Ftvk. 55. \$], de ezek más nyelveken írt információkat is tartalmazhatnak. Amennyiben az eladó a jótállásra vonatkozó nyilatkozatait tartalmazó jótállási jegyet nem adja át a vevő számára, e mulasztás a vevő számára nem járhat hátránnyal, utóbbi ebben az esetben szavatosságban vagy jótállásban ilyen okirat hiányában is részesül [449/2003. tv. 21. \$ (2) bekezdés]. 
Az eladó által nyújtott bármely jótállás, amelyet a jótállási jegy tartalmaz, vagy amelyre reklámokban történt utalás, kötelező az eladóra nézve (449/2003. tv. 19. \$). Bármely, ilyen jótállás alapján az eladó által kibocsátott (a 449/2003. tv. 20. \-ában szabályozott) jótállási jegyet a laikusok számára érthető módon kell megfogalmazni és annak tartalmaznia kell a tájékoztatást, miszerint a jótállás mint szerződéses egyezség, feltételei nem ronthatják le a fogyasztók számára a szavatosságból fakadó jogokat. A jótállási jegynek tartalmaznia kell az eladó és a termék megjelölését, és azt az időtartamot, amelyre a jótállás szól, a termék átlagos használati idejét rendeltetésszerủ használata esetén és azokat a jogokat is, amelyekkel a fogyasztó a jótállás alapján rendelkezik (például a termék karbantartása, kijavítása, kicserélése) illetve azon személyek/szervek megjelölését, amelyek számára az eladó a termék szervizelését engedélyezte.

Főszabály szerint a fogyasztónak bizonyítania kell, hogy a termék nem volt megfelelő abban az időpontban, amikor azt átvette, annak érdekében, hogy a szavatosságra hivatkozhasson (449/2003. tv. 9. \$). A bizonyítási teher a 449/2003. tv. 18. \$-a értelmében [amely az 1999/44/EK irányelv 5. cikkének (3) bekezdését ülteti át] minden esetben megfordul, amikor a meg nem felelés a termék átadását követő hathónapos határidőn belül kerül észlelésre. ${ }^{66} \mathrm{~A}$ felek e szabálytól egyezségükben eltérhetnek a fogyasztónak kedvezőbb rendelkezésekkel, ha az eladó jótállást is biztosít.

A fogyasztó a meg nem felelés elhárítását a jogszabályban elöírt bármely módon kérheti a szavatosság alapján, de a jótállásra hivatkozva ezek mellett más intézkedésekre is jogosult lehet.

A fogyasztó szavatossági eredetű jogosultságai a termék kijavítása, illetve kicserélése - ha ezek nem minősülnek aránytalannak -, ellenkező esetben pedig a vételár arányos csökkentése (ha a vételár kifizetésre került, visszaszolgáltatása). Az eladó köteles ezen intézkedéseket foganatosítani, amennyiben a meg nem felelésre a termék átadásától számított kétéves határidőn belül került sor, és ezt a vevő az eladó tudomására hozta, az észleléstől számított kéthónapos határidőn belül. A meg nem felelést az eladónak tizenöt napos határidőn belül kell elhárítania, illetve rövidebb határidőn belül, ha erről a felek között írásos egyezség született. A tizenöt napos határidő kiterjesztése az eladó és a vevő egyezsége alapján sem lehetséges.

66 E határidő szintén kógens. I.-F. Popa: i. m., 2007. Lásd továbbá F. Tudoriu, C. A. Popârțac: i. m., 159-160. 


\section{A fogyasztó egyéb igényérvényesítési lehetőségei a szavatosságon és jótálláson túl}

A román fogyasztóvédelmi jogban, nem megfelelő teljesítés esetére a 449/2003. tv. által szabályozott adásvételi szerződésekben, a fogyasztók számára a szavatosság és - amennyiben alkalmazandó -, a jótállás jogcímein kívül más jogcím nem biztosított. Ahogyan azt fentebb már említettük, az eladó a vevővel szemben további kötelezettségeket vállalhat egy különálló kiterjesztett jótállás útján, amely a vevő számára további fizetési kötelezettség ellenében biztosítható, de ez nem képezi a 449/2003. tv. szabályozásának tárgyát, ez esetben az RPtk. rendelkezései alkalmazandók.

A fogyasztói egyesületek keresetet indíthatnak (ahogyan azt lentebb ismertetjük) annak érdekében, hogy a 449/2003. tv. által szabályozott ügyletekben résztvevő eladókat törvénysértő magatartásuk megszüntetésére kötelezzék. E keresetek azonban nem biztosítanak jogvédelmet az egyes fogyasztók számára nem megfelelő teljesítés esetére, így elsődlegesen megelőző természetűek.

\section{A szavatossági és jótállási igények érvényesítésének szabályai}

A fogyasztó követelését peres eljárásban kényszerítheti ki az eladóval szemben, amennyiben utóbbi nem hozza meg azokat az intézkedéseket a termék megfelelésének helyreállítására, amelyekre a fogyasztó jogosult. Ez a per a rendes peres eljárás szabályai szerint zajlik, amelyeket a román Polgári eljárásjogi törvénykönyv (a továbbiakban: RPp.) tartalmaz. Az RPp. 113. \$-ának 8. pontja értelmében a „nem-vállalkozóknak” (vagyis a fogyasztóknak) a keresetet az eladó lakóhelye szerint illetékes bíróság mellett a saját lakóhelyük szerint illetékes bíróság előtt is jogukban áll előterjeszteni. ${ }^{67}$

A fogyasztók és kereskedők között keletkezett jogviták alternatív megoldásáról szóló 2015. évi 38. kormányrendelet ${ }^{68}$ lehetővé teszi alternatív vitamegoldási rendszerek (alternative dispute resolution - ADR) alkalmazását

67 M. Dinu: Aspecte procesuale referitoare la cererile în justiție în raportul dintre profesioniști și consumatori. In: Pandectele Române, 2019/5. 52.

68 A fogyasztók és kereskedők között keletkezett jogviták alternatív úton megoldásáról szóló 2015. évi 38. kormányrendelet [Ordonanța 38/2015 privind soluționarea alternativă a litigiilor dintre consumatori și comercianți Dată act: 26-aug-2015] a román Hivatalos Közlöny 654/2015.08.28. számában került közzétételre. A kormányrendelet ülteti át a fogyasztói jogviták alternatív rendezéséről, valamint a 2006/2004/EK rendelet és a 2009/22/EK irányelv módosításáról szóló 2013/11/EU európai parlamenti és a tanácsi irányelvet (HL L 165., 2013.6.18., 63-79.), és a fogyasztói érdekek védelme érdekében a 
a fogyasztó és a vállalkozó közötti szerződés kapcsán keletkezett jogviták kezelésére. A rendelet nem minősíti alternatív vitamegoldásnak a fogyasztó és a vállalkozó közötti közvetlen egyeztetést, illetve a per folyamán zajló egyeztetést, amelyet a bíróság kezdeményez. A rendelet tárgyi hatálya csupán olyan ADR módszerekre terjed ki, amelyek online platformok útján kezdeményezhetők [5. $\$(2)$ bekezdés a) pont]. Az egyes módszerek nem kerülnek külön-külön felsorolásra, de a rendelet megfogalmazásából levezethető, hogy a közvetités és a választottbiráskodás, ahogyan a felek harmadik személy részvételével folytatott közvetett egyeztetése is ebben a formában megengedettek. A rendelet 10 . \$-a kifejezetten lehetővé teszi az ADR szervek számára, hogy a felek közötti jogvitára megoldást javasoljanak, de azt is, hogy a jogvitát a felekre nézve kötelező módon maguk oldják meg. (Utóbbi lehetőség a román jogban a választottbíráskodás esetében fordulhat kizárólag elö.) A közvetítés folyamán legtöbbször a közvetítő nem javasol megoldást a jogvitára, de véleményünk szerint e megközelítés is megengedett, ha a felek ebbe beleegyeznek. Minden ADR módszernek meg kell felelnie a szakértelem, függetlenség, pártatlanság, eljárási átláthatóság és a tisztességes eljárás követelményeinek. ${ }^{69}$ Minden, a kormányrendelet alapján ADR-t szolgáltató szervet lajstromba kell venni. ${ }^{70}$

Mivel az ADR módszereknek a fogyasztók és vállalkozók közötti jogviták megoldására történő alkalmazását az RPp., illetve más jogforrások nem akadályozzák, úgy kell értelmeznünk, hogy a rendelet tárgyi hatálya kizárólag az elektronikus távközlés útján megvalósuló ADR-re terjed ki. Ezen ADR mechanizmusok célja elsősorban a pénzügyi szektorban keletkező jogviták megoldása. Ezt bizonyítja az a tény, hogy e területen különálló ADR intézményként hozták létre a Bankszektorban Keletkezett Jogviták Alternatív Megoldási Központját, ${ }^{71}$ miközben a fogyasztói adásvételek esetében ilyen intézmény nem létezik. A fogyasztók számára nem tiltott az „offline” ADR módszerek alkalmazása a köztük és a vállalkozók között keletkezett jogvitákban.

jogsértés megszüntetésére irányuló eljárásokról szóló 2009/22/EK európai parlamenti és a tanácsi irányelvet (fogyasztói alternatív vitarendezési irányelv, HL L 110., 2009.5.1., 30-36.), továbbá a fogyasztóvédelmi jogszabályok végrehajtásáért felelős nemzeti hatóságok közötti együttműködésről és a 2006/2004/EK rendelet hatályon kívül helyezéséről szóló (EU) 2017/2394 európai parlamenti és a tanácsi rendeletet (HL L 345., 2017.12.27., 1-26.). A kormányrendelet alkalmazásáról lásd G. Piperea: i. m., 426-431.

69 Lásd J. Goicovici: Noile proceduri de soluționare alternativă a litigiilor dintre comercianți și consumatori. Studia Universitatis Babeș-Bolyai Iurisprudentia, 2015/4. 56-57.

70 G. Piperea: i. m., 427. A fogyasztóvédelmi adásvételek terén az ADR szervezetek listája nem tartalmaz ilyen intézményeket. (https://anpc.ro/categorie/1271/sal, letöltés dátuma: 2020.02.25.)

71 J. Goicovici: i. m., 55. Lásd továbbá a 70. jegyzetet fentebb. 
A román fogyasztóvédelmi jogban különös szerep jut a fogyasztók jogainak védelmében alapított egyesületek számára, mivel ezeket a 449/2003. tv. által adott meghatározás magukkal a fogyasztókkal azonos státusba helyezte. Az ilyen egyesületekre vonatkozó jogi normák a 21/1992. Korm. r. 30-43\$-aiban kerülnek felsorolásra. Fogyasztóvédelmi egyesületek alapítása a nem-kormányzati (civil) szervezetekre vonatkozó általános jogszabályok alapján lehetséges ${ }^{72}$ a fogyasztók jogainak védelme céljából. Az így alapított egyesületek a fogyasztók jogai és jogos érdekei védelmében keresetindítási joggal rendelkeznek [21/1992. Korm. r. 37. $\$ \mathrm{~h}$ ) pont]. A kormányrendelet nem korlátozza az így indítható kereseteket, emiatt felvetődik a kérdés: megengedett-e számukra egyes fogyasztók érdekében a keresetindítás, vagy ez csupán azon fogyasztók esetében lehetséges, akik az egyesület tagjai (mikor a kereset tulajdonképpen egy csoportpert ${ }^{73}$ keletkeztetne), illetve megengedett-e számukra a közérdekü keresetindítás (actio popularis). ${ }^{74}$

Nézetünk szerint ezek az egyesületek nem indíthatnak keresetet és nem kezdeményezhetik bírósági határozatok végrehajtását egyéni fogyasztók érdekében, ha az érintett fogyasztók az egyesületnek nem tagjai. Az RPp. 83. \-ának értelmében föszabály szerint magánjogi jogi személyek nem képviselhetnek természetes személyeket meghatalmazás alapján a bíróságok előtt (a meghatalmazás hiánya pedig sértené a rendelkezési elvet). E jogosultság természetes személyek, elsősorban ügyvédek számára van fenntartva. A fogyasztóvédelmi egyesületeknek ellenben joguk van keresetet indítani tagjaik nevében (csoportpert kezdeményezve, ha tagjaik azonos eladó nem megfelelö teljesítésének következményeit szenvedték el), vagy akár a közérdek védelmében is. ${ }^{75} \mathrm{~A}$ folyamatban lévő perekbe beavatkozóként ${ }^{76}$ beléphetnek a fogyasztó érdekeinek védelmében. Az eladó nem szerződésszerű teljesítésével kapcsolatos perekben, fogyasztói adásvételi szerződésekre vonatkozóan elsősorban az utóbbi és kevésbé az előbbi megoldás képzelhető el, ugyanis a közérdekü keresetindítás esetében a fogyasztóvédelmi egyesületek nem érvényesíthetnek konkrét kereseti kérelmeket a nem megfelelő teljesítés elhárítására, csupán azt kényszeríthetik ki az eladótól, hogy a jövőben bizonyos magatartásokat tanúsítson, vagy ezektől tartózkodjon. ${ }^{77}$

72 Lásd M. Iliescu: i. m., 2014, 438-439. Lásd továbbá A. N. Gheorghe, C. Spasici, D. S. Arjoca: i. m., 341-346.

73 Lásd G. Piperea: i. m., 411-412.

74 Lásd F. Tudoriu, C. A. Popârțac:. i. m., 167-168.

75 M. Dinu: Considerații privind calitatea procesuală în litigiile dintre consumatori și profesioniști. Curierul Judiciar, 2015/8. 428.

76 M. Dinu: i. m., 2019, 50.

77 M. Dinu: i. m., 2019, 429. 
A Nemzeti Fogyasztóvédelmi Hatóság ${ }^{78}$ nincs feljogosítva fogyasztói követelések közvetlen érvényesítésére, vagy az egyes fogyasztók érdekében történő eljárásra. ${ }^{79}$ Segítséget nyújthat azonban a fogyasztóvédelmi egyesületek számára és közigazgatási természetű szankciókat is alkalmazhat a vállalkozókkal szemben [a Nemzeti Fogyasztóvédelmi Hatóság szervezetésre és működésére vonatkozó 2012. évi 700. kormányhatározat 3. \$ (1) bekezdés j) pontja]. A hatóság továbbá támogathatja olyan szervezetek létrehozását is, amelyek közvetítenek a fogyasztók és vállalkozók között [3. $\$(1)$ bekezdés t) pont]. Az adásvételi szerződések terén más piaci megfigyelésre jogosult hatóságok nincsenek felhatalmazva a fogyasztói követelések megoldására vagy érvényesítésére.

78 A Nemzeti Fogyasztóvédelmi Hatóságot a 21/1992. Korm. r. szabályozza, de ennek hatáskörét kormányhatározatok szabják meg a rendelet 28. \$-ának értelmében. Ezek közül a legjelentősebb a Nemzeti Fogyasztóvédelmi Hatóság szervezetéről és működéséről szóló2012. évi 700. kormányhatározat (Hotărârea 700/2012 privind organizarea și funcționarea Autorității Naționale pentru Protecția Consumatorilor), amely a román Hivatalos Közlöny 491/2012.07.18. számában került közzétételre.

79 F. Tudoriu, C. A. Popârțac:. i. m., 189-193. 


\section{Forrásjegyzék}

1. R. D. Apan: Repere în definirea noțiunii de consumator. Pandectele Române, különszám 2008. március 31., elérhetö: https://www.sintact.ro/\#I publication/151001161 (letöltés dátuma: 2020.02.15.)

2. N. A. Daghie: Aspecte teoretice și practice privind condițiile cerute pentru admisibilitatea rezoluțiunii judiciare. Revista Română de Drept privat, 2009/6. 48-85.

3. M. Dinu: Aspecte procesuale referitoare la cererile în justiție în raportul dintre profesioniști și consumatori. In: Pandectele Române, 2019/5. 48-57.

4. M. Dinu: Considerații privind calitatea procesuală în litigiile dintre consumatori și profesioniști. Curierul Judiciar, 2015/8. 426.

5. A. N. Gheorghe, C. Spasici, D. S. Arjoca: Dreptul consumației. Editura Hamangiu, București, 2012.

6. J. Goicovici: Dreptul consumației. Sfera Juridică, Cluj-Napoca, 2006.

7. J. Goicovici: Elementele constitutive ale practicilor comerciale neloiale în relațiile cu consumatorii. Studia Universitatis Babeș-Bolyai Iurisprudentia, 2016/3. 88-100.

8. J. Goicovicı: Noile proceduri de soluționare alternativă a litigiilor dintre comercianți și consumatori. Studia Universitatis Babeș-Bolyai Iurisprudentia, 2015/4. 53-66.

9. N. Grădinaru: Regulile comunitare în materia vânzării bunurilor de consum și a garanțiilor acestora. Revista Română de Drept Comunitar, 2005/3.

10. A. Groza: Din jurisprudența recentă a Curții de Justiție a Uniunii Europene. Revista Forumul Judecătorilor, 2011/4. 232-235.

11. M. Iliescu: Aspecte teoretice privind noțiunea de consumator în legislația română. In: Politica legislativă între reglementare europeană, națională și internațională. Noi perspective ale dreptului, Conferința internațională de drept, studii europene și relații internaționale - București, 24-25 mai 2013, Editura Hamangiu, București, 2013. 585-594.

12. M. Iliescu: Consumatorul - între prevederi legislative și opinii doctrinare. Curierul Judiciar, 2014/8. 435-441.

13. E. Minai: Contractul de credit pentru consum în viziunea Ordonanței de urgență a Guvernului nr. 50/2010. Revista Română de Drept al Afacerilor, 2012/5. 13. 
14. E. M. Minea: Incidența reglementărilor vizând protecția consumatorilor în domeniul construcțiilor de locuințe. Revista Română de Drept al Afacerilor, 2010/9. 13.

15. D. Moțıu: Clauze abuzive în contractele încheiate cu consumatorii. Revista de Stiințe Juridice, 2013/1.

16. G. Piperea: Protecția consumatorilor în contractele comerciale. C. H. Beck, București, 2018.

17. I.-F. Popa: Conformitatea lucrului vândut - Între rigiditate tradițională și funcționalism. Revista Română de Drept Privat, 2009/1. 132-172.

18. I.-F. Popa: Conformitatea lucrului vândut - Între rigiditate tradițională și funcționalism (II). Revista Română de Drept Privat, 2009/2. 65-98.

19. I.-F. Popa: Obligația de conformitate $-\mathrm{cu}$ referire specială la vânzările de consum. Pandectele Române, 2005/5. 153-178.

20. I.-F. Popa: Regimul juridic al termenelor în materia garanției de conformitate. Revista Română de Drept Privat, 2007/4. 79-117.

21. I. Schiau: Profesionistul, un reper al dăinuirii materiei comerciale în cadrul dreptului privat unitar. Revista Română de Drept al Afacerilor, 2015/7. 43-58.

22. V. Terzea: Neexecutarea obligațiilor contractuale. Revista Română de Drept Privat, 2018/6.

23. F. Tudoriu, C. A. PopÂrțac: Drepturile consumatorului. O provocare pentru afaceri, Universul Juridic, București, 2013.

24. Az Európai Parlament és a Tanács 1999/44/EK irányelve (1999. május 25.) a fogyasztási cikkek adásvételének és a kapcsolódó jótállásnak egyes vonatkozásairól, HL L 171., 1999.7.7., 12-16.

25. Az Európai Parlament és a Tanács 2009/22/EK irányelve (2009. április 23.) a fogyasztói érdekek védelme érdekében a jogsértés megszüntetésére irányuló eljárásokról, HL L 110., 2009.5.1., 30-36.

26. Az Európai Parlament és a Tanács 2013/11/EU irányelve (2013. május 21.) a fogyasztói jogviták alternatív rendezéséről, valamint a 2006/2004/ EK rendelet és a 2009/22/EK irányelv módosításáról, HL L 165., 2013.6.18., 63-79. 
27. Az Európai Parlament és a Tanács (EU) 2017/2394 rendelete (2017. december 12.) a fogyasztóvédelmi jogszabályok végrehajtásáért felelős nemzeti hatóságok közötti együttműködésről és a 2006/2004/EK rendelet hatályon kívül helyezéséről, HL L 345., 2017.12.27., 1-26.

28. A társaságokról szóló 1990. évi 31. törvény, újra-közzétéve a román Hivatalos Közlöny 1066/2004.11.17. számában

29. A vállalkozók és fogyasztók között kötött szerződésekbe foglalt visszaélésszerű záradékokról szóló 2000. évi 193. törvény (Legea 193/2000 privind clauzele abuzive din contractele încheiate între profesioniști și consumatori), közzétéve a Hivatalos Közlöny 543/2012.08.03. számában

30. A termékek eladásáról és a hozzá füződő garanciákról szóló 2003. évi 449. törvény (Legea 449/2003 privind vânzarea produselor si garanțiile asociate acestora), újra-közzétéve a román Hivatalos Közlöny 347/2008.05.06. számában

31. 2004. évi 296. törvény a fogyasztói törvénykönyvről (Legea 296/2004 privind Codul consumului), újra-közzétéve a Hivatalos Közlöny 224/2008.03.24. számában

32. A kereskedők fogyasztókkal szembeni tisztességtelen magatartásának visszaszorításáról és a jogszabályok az európai fogyasztóvédelmi joggal történő harmonizálásáról szóló 2007. évi 363. törvény (Legea 363/2007 privind combaterea practicilor incorecte ale comercianților in relația cu consumatorii și armonizarea reglementărilor cu legislația europeană privind protecția consumatorilor), közzétéve a Hivatalos Közlöny 899/2007.12.28. számában

33. 2009. évi 287. törvény a polgári törvénykönyvröl (Codul civil), újra-közzétéve a Hivatalos Közlöny (Monitorul Oficial) 505/2011.07.15. számában

34. A termékek eladására és a hozzá füződő garanciákra vonatkozó 2003. évi 449. törvény módosítására vonatkozó 2016. évi 9. kormányrendelet jóváhagyásáról szóló 2018. évi 353. törvény (Legea 353/2018 privind aprobarea Ordonanței Guvernului nr. 9/2016 pentru modificarea și completarea Legii nr. 449/2003), közzétéve a Hivatalos Közlöny 4/2019.01.03. számában

35. A fogyasztók védelméről szóló 1992. évi 21. kormányrendelet (Ordonanța 21/1992 privind protecția consumatorilor) újra-közzétéve a Hivatalos Közlöny 208/2007.03.28. számában 
36. Az egyesületekről és alapítványokról szóló 2000. évi 26. kormányrendelet, közzétéve a román Hivatalos Közlöny 39/2000.01.31. számában

37. Az engedélyezett természetes személyek, egyéni vállalkozások és családi vállalkozások általi gazdasági tevékenységek gyakorlására vonatkozó 2008. évi 44. sürgősségi kormányrendelet (Ordonanța de urgență 44/2008 privind desfășurarea activităților economice de către persoanele fizice autorizate, intreprinderile individuale și intreprinderile familiale), közzétéve a Hivatalos Közlöny 328/2008.04.25. számában

38. A fogyasztók és kereskedők között keletkezett jogviták alternatív úton megoldásáról szóló 2015. évi 38. kormányrendelet (Ordonanța 38/2015 privind soluţionarea alternativă a litigiilor dintre consumatori și comercianți Dată act: 26-aug-2015), közzétéve a Hivatalos Közlöny 654/2015.08.28. számában

39. Egyes fogyasztóvédelmi vonatkozású jogszabályok módosításáról és kiegészítéséről 2008. évi 174. sürgősségi kormányrendelet (Ordonanța de urgență 174/2008 pentru modificarea și completarea unor acte normative privind protecția consumatorilor), közzétéve a Hivatalos Közlöny 795/2008.11.27. számában

40. A Nemzeti Fogyasztóvédelmi Hatóság szervezetéről és működéséről szóló 2012. évi 700. kormányhatározat (Hotărârea 700/2012 privind organizarea și funcționarea Autorității Naționale pentru Protecția Consumatorilor), közzétéve a Hivatalos Közlöny 491/2012.07.18. számában

41. Európai Unió Bíróságának C-269/95. sz. Francesco Benincasa v. Dentalkit Srl ügyben 1997. július 3-án hozott ítélete (ECLI:EU:C:1997:337)

42. Európai Unió Bíróságának C-464/01. sz. Johann Gruber v. Bay Wa $A G$ ügyben 2005. január 20-án hozott ítélete (ECLI:EU:C:2005:32)

43. Európai Unió Bíróságának C-65/09. sz. Gebr. Weber GmbH v. Jürgen Wittmer és C-87/09 Ingrid Putz v. Medianess Electronics GmbH egyesített ügyekben 2011. június 16-án hozott ítélete (ECLI:EU:C:2011:396)

44. Európai Unió Bíróságának C-110/14. sz. Horațiu Ovidiu Costea v. SC Volksbank România SA ügyben 2015. szeptember 3-án hozott ítélete (ECLI:EU:C:2015:538)

45. Legfelsőbb Semmítő- és Ítélőszék Második Polgári Kollégiumának 2016. március 2-i 441/2016.sz. határozata

46. Legfelsőbb Semmítő- és Ítélőszék Második Polgári Kollégiumának 2017. január 26-i 115/2017. sz. határozata 
47. Legfelsőbb Semmítő- és Ítélőszék, Második Polgári Kollégiumának 2018. február 2-i 479/2018. sz. határozata

48. Legfelsőbb Semmítő- és Ítélőszék 2018. június 4-i 37/2018. sz. határozata

49. Nagyváradi Ítélőtábla, 2019. május 7-i 158/2019. sz. polgári ügyben hozott határozata (https://www.sintact.ro, letöltés dátuma: 2020.02.12.)

50. Bihar Megyei Törvényszék, 2018. július 5-i 166/2018. sz. polgári ügyben hozott határozata

51. 2008. évi 174. sürgősségi kormányrendelet indokolása, elérhető: http:// arhiva.gov.ro/upload/articles/103997/2763-nf-protectia-consumatorilor-tot. $p d f$, letöltés dátuma: 2019.12.20

52. https://eur-lex.europa.eu/legal-content/EN/NIM/?uri=celex:31999L0044, letöltés dátuma: 2020.01.12.

53. https://anpc.ro/categorie/1271/sal, letöltés dátuma: 2020.02.25.

54. https://www.sintact.ro 
FOGYASZTÓI ADÁSVÉTEL EGYES KÉRDÉSEI - ROMÁNIA

Dr. Székely János PhD., a kolozsvári Babeș-Bolyai Tudományegyetem Jogtudományi Karán 2007-ben szerzett jogász ovégzettséget. Ezután tanulmányait tovább folytatta az intézmény falai között, 2008-ban európai magánjogi szakirányú mesteri (LLM) oklevelet szerezve. Doktori tanulmányait a Debreceni Egyetem Marton Géza Állam- és Jogtudományi Doktori Iskolájának keretein belül teljesítette, 2017-ben szerzett doktori fokozatot államés jogtudományok terén, summa cum laude minősítéssel. 2007-ben fordítói engedélyt szerzett román és magyar nyelv viszonylatában. 2008-ban felvételt nyert a romániai Satu Mare (Szatmár) Megyei Ügyvédi Kamarába. 2010-től teljes jogú ügyvéd, 2011-től engedélyezett közvetítő. 2012-től a Sapientia Erdélyi Magyar Tudományegyetem, Kolozsvári Kar, Jogtudományi Intézetének kinevezett oktatója, 2017-től fóállású egyetemi adjunktusa. A polgári eljárásjog, öröklési jog, jogi kultúrtörténet (II.) elnevezésű tárgyak oktatója. 2019-től a Satu Mare Megyei Ügyvédi Kamara tanácsának tagja. 